\title{
Use and Abuse of Bargaining Models in Antitrust
}

\author{
Joshua D. Wright ${ }^{*} \&$ John M. Yun ${ }^{* *}$
}

\section{INTRODUCTION}

Bargaining is all around us. We are generally most familiar with bargaining when negotiating the prices, terms, and conditions of durable goods such as homes and automobiles. Yet bargaining is how prices are set across a range of economic activities such as between licensors and licensees of intellectual property, employees and employers, content providers and distributors, health insurers and hospitals, and in many intermediate product markets. However, unlike the standard economic paradigm of a single-price set through the interactions of supply and demand, understanding price in a bargaining setting involves a different set of tools and insights. Economics has filled this void through the development of bargaining models that began in earnest with the dawn of mathematical game theory in the 1940s and 1950s. ${ }^{1}$

Recently, bargaining has played a central role in a number of highprofile antitrust matters. In 2018, the U.S. Department of Justice (DOJ) challenged AT\&T's acquisition of Time Warner-largely on the basis of a bargaining model that predicted the combined firm would have the ability and incentive to extract higher prices for its Turner Network television stations from downstream content distributors such as the Dish Network. $^{2}$ In another example from 2018, the U.S. Federal Trade Commission argued that Qualcomm's market position in cellular chipsets allowed it to leverage higher royalty rates for its standard essential patents

\footnotetext{
* University Professor, Antonin Scalia Law School, George Mason University; Executive Director of the Global Antitrust Institute; and a former U.S. Federal Trade Commissioner.

** Associate Professor, Antonin Scalia Law School, George Mason University; Director of Economic Education at the Global Antitrust Institute; and a former Acting Deputy Assistant Director in the Bureau of Economics, U.S. Federal Trade Commission. We thank Scalia Law students Nicole Booth and Keith Holleran for invaluable research assistance.

1. Seminal works include: JoHn vOn Neumann \& OSKAR Morgenstern, The TheORY of Games And ECONOMic Behavior (1944); John F. Nash, Jr., The Bargaining Problem, 18 ECONOMETRICA 155 (1950).

2. See United States v. AT\&T, Inc., 310 F. Supp. 3d 161, 164 (D.D.C. 2018), aff'd, 916 F.3d 1029 (D.C. Cir. 2019). Turner Network is comprised of ten cable channels: TNT, TBS, CNN, CNN Español, CNN International, Cartoon Network/Adult Swim, truTV, Turner Classic Movies, Boomerang, and HLN. Id. at 179 n.7.
} 
(SEPs), in violation of its commitment to license its SEPs on fair, reasonable, and non-discriminatory (FRAND) terms. ${ }^{3}$ Yet, bargaining models are certainly not new in antitrust. They have been used in assessing hospital mergers as well as prior matters similar to the AT\&TTime Warner matter, which involved bargaining between content providers and programming distributors - often labeled multichannel video programming distributors (MVPDs). ${ }^{4}$

Yet, as we detail in this article, bargaining models have been unevenly adopted by the courts - particularly for vertical mergers. ${ }^{5}$ Further, a close cousin to bargaining models for vertical mergers, the vertical gross upward pricing pressure index (GUPPI), has yet to be formally adopted by the agencies. ${ }^{6}$ We explore the reasons why courts and agencies have yet to uniformly adopt these vertical versions of upward pricing pressures and simulation. Ultimately, while the rationales of particular judges might be heterogeneous, uneven, and perhaps, at times, inconsistent with core economic logic, the fundamental point is that judges do not uniformly find the tools predictive and useful for determining the potential anticompetitive effects from vertical mergers. Of course, some courts have adopted bargaining models, including for hospital mergers, which is the point of the analysis - to determine why there is such irregular treatment of these models.

In this article, we assess the value of economic bargaining models to predict outcomes for both horizontal and vertical mergers and for unilateral conduct. To that end, we first provide an overview of the economics of bargaining models and their primary features, including the vertical GUPPI variant. ${ }^{7}$ We then discuss these models in the context of recent antitrust cases and detail the uneven judicial adoption of bargaining models. ${ }^{8}$ Next, we examine whether the current judicial reticence is

3. See Fed. Trade Comm'n v. Qualcomm, Inc., No. 17-CV-00220, 2018 WL 5848999, at *1 (N.D. Cal. Nov. 6, 2018).

4. See, e.g., Fed. Trade Comm'n v. Advocate Health Care, No. 15-C-11473, 2017 WL 1022015, at *10 (N.D. Ill. Mar. 16, 2017) (discussing issues resulting from a hospital merger); Limelight Networks, Inc. v. XO Commc'ns, LLC, No. 3:15-CV-720, 2018 WL 678245, at*1 (E.D. Va. Feb. 2, 2018) (reviewing objections to expert testimony for two content delivery networks in patent infringement litigation); Laumann v. Nat'l Hockey League, 117 F. Supp. 3d 299, 322 (S.D.N.Y. 2015) (analyzing bargaining methods between regional sports networks (RSNs) and MVPDs); Behrend v. Comcast Corp., 264 F.R.D. 150, 179 (E.D. Pa. 2010), aff'd, 655 F.3d 182 (3d Cir. 2011), rev'd, 569 U.S. 27 (2013) (discussing expert testimony in a class action against cable provider, Comcast).

5. See infra Part III.

6. The vertical GUPPI was proposed in Serge Moresi \& Steven C. Salop, vGUPPI: Scoring Unilateral Pricing Incentives in Vertical Mergers, 79 ANTITRUST L.J. 185, 186 (2013).

7. See infra Part II.

8. See infra Part III. 
justified. ${ }^{9}$ We review a body of emerging scholarship that suggest some caution on the use of methodologies to predict harm based on bargaining models. ${ }^{10}$ This suggests that a healthy degree of judicial skepticism is warranted-whether coherently articulated in opinions or not. In conclusion, we offer some policy recommendations for the use of bargaining models, which we believe will lead to a more balanced approach regarding their use in antitrust matters. ${ }^{11}$

\section{THE ECONOMICS OF BARGAINING MODELS}

At its essence, bargaining is a method to set price and the terms of trade. ${ }^{12}$ Customarily, we consider a market economy as setting price through the interaction of demand and supply. ${ }^{13}$ While this is certainly true for many markets, Dov Rothman and David Toniatti succinctly make the point when they state "[p]rices are determined in different ways in different markets." ${ }^{14}$ More specifically, in settings such as negotiations between content suppliers and distributors, insurance providers and hospitals, and wholesalers and retailers, prices are set through a bargaining process rather than through a market-wide determined price via supply and demand. ${ }^{15}$

The central reason why two parties engage in bargaining is because there are "gains-from-trade." 16 However, predicting bargaining outcomes - even merely directionally - involves imposing some structure on the bargaining problem and process. The fundamental problem that bargaining models are trying to solve is how the economic surplus from a

9. See infra Part IV.

10. See, e.g., Margaret Slade, Vertical Mergers: Ex Post Evidence and Ex Ante Evaluation Methods (Vancouver School of Economics, Working Paper, 2019); Gopal Das Varma \& Martino De Stefano, Equilibrium Analysis of Vertical Mergers (Dec. 10, 2018), https://papers.ssrn.com/sol3 /papers.cfm?abstract_id=3307150 [https://perma.cc/D42Q-JBSV] (unpublished manuscript); Gleb B. Domnenko \& David S. Sibley, Simulating Vertical Mergers and the Vertical GUPPI Approach (Jan. 1, 2019), https://papers.ssrn.com/sol3/papers.cfm?abstract_id=3447687 [https://perma.cc/3WC3GXC2] (unpublished manuscript); Christopher Garmon, The Accuracy of Hospital Merger Screening Methods, 48 RAND J. ECON. 1068, 1097 (2015).

11. See infra Part V.

12. Bargain, CAMBRIDGE DICTIONARY, https://dictionary.cambridge.org/us/dictionary/english /bargaining [https://perma.cc/WTD2-M8VC] (last visited Mar. 22, 2020).

13. See generally Alfred Marshall, PRINCIPLES OF ECONOMICS (1890).

14. Dov Rothman \& David Toniatti, A Primer on Bargaining: How Mergers May Affect Negotiated Prices, ANTITRUST SOURCE, Apr. 2018, at 1, 1.

15. Id.

16. See id. ("There are gains-from-trade if the 'gross benefit' the intermediary gets from purchasing from the supplier is greater than the cost the supplier incurs in selling to the intermediary."). 
voluntary and mutually beneficial exchange is divided. ${ }^{17}$ Further, how do incentives and bargaining outcomes change when market conditions change, such as when there is a horizontal or vertical merger? Put simply, bargaining models are methodologies, tools, and guidelines that economists use to put some order into the process of negotiation in terms of how to split the surplus or gains from trade resulting from a transaction. $^{18}$

Broadly, often the objective of bargaining models is not to derive a precise prediction regarding the agreed upon price — particularly given that price is only one of a variety of actual factors that parties bargain over. The reality is that almost all actual bargaining negotiations are multifaceted. ${ }^{19}$ Specifically, other terms that are relevant to a bargaining process - which ultimately could impact price in some manner-include the length of the contract, contingencies for risk, degree of asset specificity and investment, frequency of interaction, priority of access in times of shortages, insurance for non-delivery, exchange of technologies, and assurances of supply. ${ }^{20}$ Most bargaining models abstract from these complexities because their inclusion would naturally increase the complexity and information burden of these models. ${ }^{21}$ However, the fact that these complexities are not modeled does not mean they are irrelevant or that their omission does not impact the quality of the price predictions. Of course, there is an argument that, as applied to mergers, there is no reason to believe that these nonprice terms would change post-merger; consequently, we can still make an apples-to-apples comparison between the pre- and post-merger bargaining outcome. While this argument is

17. See Alvin E. Roth, Axiomatic Models of Bargaining 1 (1979) ("If there are feasible outcomes which all the participants prefer to the disagreement outcome, then there is an incentive to reach an agreement; however, so long as at least two of the participants differ over which outcome is most preferable, there is a need for bargaining and negotiations over which outcome should be agreed upon.").

18. Of course, bargaining and negotiations are topics that impact scholarship outside of economics including political science, labor relations, and business management. See, e.g., Samuel B. Bacharach \& Edward J. Lawler, Power and Tactics in Bargaining, 34 INDUS. \& LAB. REL. REV. 219 (1981); Daniel Druckman, Negotiating in the International Context, in PEACEMAKING IN INTERNATIONAL CONFLICT: METHODS AND TECHNIQUES 81 (I. William Zartman \& J. Lewis Rasmussen eds., 1997); Christopher Voss, NeVER Split The DifFERENCE: Negotiating As IF YOUR LIFE DEPENDED ON IT (2016).

19. See, e.g., P.D.V. Marsh, Contract Negotiation Handbook 64 (3d ed. 2001) ("Negotiations for a contract are always multi-faceted, covering the price, delivery, specification and the key terms of contract.").

20. See id.

21. See, e.g., ERNEST GELlHORN ET AL., ANTITRUST LAW AND ECONOMICS IN A NuTSHELl 67 (5th ed. 2004) ("Though merely theoretical constructs, structural economics models yield predictions about likely firm and market behavior. These models are analytic tools, however, and they do not completely explain real world markets.”). 
ostensibly appealing, it is a very strong assumption. ${ }^{22}$ Nonetheless, given that this line of research is relatively unexplored, we focus solely on bargaining models' prediction on price.

The origins of the modern thinking on bargaining is from Nobel Prize winning economist John Nash. ${ }^{23}$ Using an axiomatic approach, the Nash bargaining model predicts how a bargaining surplus is split in bilateral negotiations, which involves maximizing the (product of the) utility of all the parties involved in the negotiation. ${ }^{24}$ A central component of the Nash model involves an explicit incorporation of the disagreement outcome. ${ }^{25}$ The Nash solution is the only solution that satisfied a series of axioms that Nash established, which includes conditions of symmetry, Pareto efficiency, invariance to transformations, and Independence of Irrelevant Alternatives. $^{26}$

There are a number of key aspects of bargaining models that are particularly relevant to antitrust applications, which we consider in this Part. First, it is important to distinguish between two related, but distinct, terms: bargaining power and bargaining leverage. ${ }^{27}$ While these terms are often used interchangeably, it is important to make a distinction between the two concepts that they capture. Second, it is important to distinguish between bargaining in the context of horizontal mergers, e.g., combining two hospitals, and vertical mergers, e.g., combining media content distributors and MVPDs. ${ }^{28}$ Finally, it is constructive to relate bargaining models for both horizontal and vertical mergers with their close cousins, the standard differentiated Bertrand model and the vertical GUPPI, respectively. ${ }^{29}$ In doing so, we will see that bargaining models and their

22. Moreover, the magnitude of the effects of these non-price variables could influence the magnitude of the predicted price change even if the non-price variables do not change post-merger.

23. John F. Nash, Jr., supra note 1, at 155. The research on bilateral monopolies and bargaining goes back much further, however, and includes the work of economists such as Cournot, Edgeworth, Pigou, Schumpeter, and von Stackelberg. For a history of the early literature on bilateral monopoly, see Fritz Machlup \& Martha Taber, Bilateral Monopoly, Successive Monopoly, and Vertical Integration, 27 ECONOMICA 101 (1960).

24. Machlup \& Taber, supra note 23, at 103. An axiomatic approach is essentially about defining a set of rules, or properties, that a solution must be consistent with and determining the potential set of outcomes that are consistent with those rules. See, e.g., HANS J. M. PETERS, AXIOMATIC BARGAINING GAME THEORY 1 (1992) ("Axiomatic bargaining game theory is concerned with a mathematical investigation of the properties of such bargaining solutions. Usually, following Nash (1950), one formulates desirable properties for these solutions, and then tries to characterize a solution or a class of solutions by its properties.”).

25. Alvin E. Roth \& Uriel G. Rothblum, Risk Aversion and Nash's Solution for Bargaining Games with Risky Outcomes, 50 ECONOMETRICA 639, 640 (1982).

26. See Nash, supra note 1 , at 156; see also RoTH, supra note 17 , at 10-11.

27. See infra Section II.A.

28. See infra Section II.B.

29. See infra Section II.C. 
close cousins have a great deal in common and rely on essentially the same set of assumptions and inputs. Consequently, concerns regarding the adoption of vertical GUPPIs, for instance, generally translate into concerns regarding vertical bargaining models and vice versa.

\section{A. Bargaining Power vs. Bargaining Leverage}

Following Aviv Nevo and Matthew Grennan, we use the term "bargaining power" to describe a negotiator's ability to extract more of a given level of joint surplus from a mutually beneficial exchange. ${ }^{30}$ This ability can be due to a variety of reasons, including superior bargaining skills and tactics, greater patience (modeled as a low discount rate for future payoffs), and less risk aversion. ${ }^{31}$ In contrast, we use the term "bargaining leverage" to describe how changes in the opportunity cost of striking a deal impacts the terms of the deal. ${ }^{32}$ In other words, bargaining leverage is based on the relative attractiveness of the best "outside option," i.e., the payoff from not striking a deal. ${ }^{33}$ Other terms that are commonly used for the best outside option include the "disagreement outcome," the "threat point" value, or "best alternative to a negotiated agreement" (BATNA). ${ }^{34}$

As we describe further below, in the context of antitrust cases, bargaining power is typically assumed to be equal between the partiesat least, this is the starting point of the analysis. Thus, it is not a variable that is considered to change post-merger, and, consequently, does not contribute to the post-merger price prediction. The origin of this assumption is that, in Nash's original formulation, the negotiating parties both have the same utility function. ${ }^{35}$ Thus, for a given level of joint surplus, they split it evenly. ${ }^{36}$ For instance, in both the Comcast-NBCU and AT\&T-Time Warner matters, the Federal Communications Commission (FCC) and the DOJ, respectively, assumed that the upstream and downstream negotiating parties had equal bargaining power and split

30. Aviv Nevo, Deputy Assistant Att'y Gen., Antitrust Div., U.S. Dep't of Justice, Mergers that Increase Bargaining Leverage, Remarks Prepared for Stanford Institute for Economic Policy Research and Cornerstone Research Conference on Antitrust in Highly Innovative Industries (Jan. 22, 2014); see also Matthew Grennan, Bargaining Ability and Competitive Advantage: Empirical Evidence from Medical Devices, 60 MGMT. SCI. 3011 (2014). Matthew Grennan uses the term bargaining "ability" rather than "power." Id. at 3011.

31. See Nevo, supra note 30, at 4; Grennan, supra note 30, at 3020.

32. See Nevo, supra note 30 , at 6 .

33. Id.

34. See Roger Fisher \& William Ury, Getting to Yes: Negotiating Agreement Without Giving IN (Bruce Patton ed., 1981).

35. Nash, supra note 1 , at 159.

36. Id. 
the surplus evenly. ${ }^{37}$

For illustrative purposes, we can represent the buyer's maximum valuation and seller's minimum valuation from a deal as $V_{B}$ and $V_{S}$, respectively. Further, we can represent the gains from trade as $G=V_{B}-$ $V_{S}$. Thus, if $G>0$, then we have a positive joint surplus and an exchange would be mutually beneficial. Absent other considerations, both parties would engage in trade-irrespective of how the surplus is actually split. We would call this a "bargaining situation," where parties have an incentive to cooperate but have some conflicting interests. ${ }^{38}$ It is worth emphasizing this fundamental principle of bargaining, where, even a very one-sided outcome would result in both parties being better off in terms of their utility. ${ }^{39}$ Of course, if we introduce non-pecuniary considerations such as the disutility from agreeing to a one-sided bargain, then it could change particular bargaining outcomes. ${ }^{40}$ Yet, bargaining models are intended to capture general, directional incentives, and the incentives are strong to engage in a transaction if there is "money on the table."

The next relevant question is in regard to the actual price at which the exchange will occur. The feasible range for the price, $P$, can be represented as: $V_{S} \leq P \leq V_{B}$. Given this range, price is determined by the relative amount of bargaining power of the buyer and seller, $\alpha$ and $(1-$ $\alpha$ ), respectively: $P^{*}=\alpha V_{B}+(1-\alpha) V_{S}$. Assuming equal bargaining power, then $P^{*}=\frac{1}{2}\left(V_{B}+V_{S}\right)$. This assumption, however, is almost

37. See Expert Report of Carl Shapiro at 42 n. 170, United States v. AT\&T, Inc., 310 F. Supp. 3d 161 (D.D.C. 2018), aff'd, 916 F.3d 1029 (D.C. Cir. 2019) [hereinafter Shapiro Report] ("Unless there is clear evidence suggesting otherwise, assuming that the gains from trade are split 50/50 is a reasonable and practical working assumption. However, if one is not willing to make that assumption, then using the Nash Bargaining framework to predict the level of the negotiated price can be difficult, unless one has evidence regarding how the gains from trade are split."); William P. Rogerson, $A$ Vertical Merger in the Video Programming Industry: The Case of Comcast-NBCU, in THE ANTITRUST Revolution: ECONOMiCS, COMPETITION, AND POLiCy 534, 545 (John E. Kwoka, Jr. \& Lawrence J. White eds., 6th ed. 2014) ("The FCC concluded that this was sufficient evidence to justify using an estimate of $\mu$ [bargaining strength parameter] that was equal to $1 / 2$ for the case of national cable networks.").

38. See Abhinay Muthoo, Bargaining Theory and Royalty Contract Negotiations, 3 REV. ECON. RES. ON COPYRIGHT ISSUES 19, 20 (2006).

39. An extreme example of this is the baseline bargaining model called the "ultimatum game," where one party makes a single take-it-or-leave it offer to the other party. In this game, two parties have valuations that would result in gains from trade, yet the party making the offer effectively takes the entire surplus as it is better for the other party to accept some small, nominal amount rather than nothing at all. See William Spaniel, Game ThEORY 101 (2011). Yet, experimental work within this simple ultimatum game indicates that actual outcomes deviated from theoretical predictions due to considerations such as perceived "fairness," which manifested itself in players "punishing" the other player for asking too much - even if this reduced their own monetary payoff. See Werner Güth et al., An Experimental Analysis of Ultimatum Bargaining, 3 J. ECON. BEHAV. \& ORGS. 367 (1982).

40. See, e.g., Colin Camerer \& Richard H. Thaler, Anomalies: Ultimatums, Dictators and Manners, 9 J. ECON. PERSP. 209, 211 (1995). 
inevitably wrong, ${ }^{41}$ but it does not mean that it is not useful or a reasonable benchmark. In the context of merger analysis, the nature of the work is to forecast the change in price, if any, from the acquisition. If we assume a given level of relative bargaining power, there is no a priori reason to believe that it would change post-merger. ${ }^{42}$ Further, it assumes away socially unproductive bargaining behavior such as haggling, which can shrink the gains from trade-yet it remains a feature of real-world bargaining since there are private gains from engaging in it. ${ }^{43}$

While bargaining power is often assumed to be evenly split, there are factors that can influence bargaining power, which are worth noting. The first is the relative patience of the negotiating sides. This is the central result of Ariel Rubinstein's seminal work on bargaining. ${ }^{44}$ Rubinstein showed that in a game of repeated offers and counteroffers, with no known end period, the surplus is split based on the relative patience, or discount rates for future payoffs, of the participants. ${ }^{45}$ If the two sides are equally patient, then the result is approximately the Nash bargaining power assumption of a 50/50 split. ${ }^{46}$ Similarly, differences in risk aversion between the two sides can also influence the split of the surplus. ${ }^{47}$

Given that bargaining power is $50 / 50$ and that there are no changes to bargaining power post-merger, the focus then turns to changes in bargaining leverage. Bargaining leverage, again, is based on the opportunity cost from not reaching an agreement. It can also be considered

41. See, e.g., Grennan, supra note 30, at 3011 ("[T] he final negotiated price depends not only on the range of prices over which negotiation occurs but also on where firms end up within this range. This latter aspect has received less attention, despite the fact that it can be important, especially in cases where the range over which negotiations occur is large and firms vary in their bargaining abilities - the ability to reach a more favorable point within the range determined by costs, willingness to pay, and competition."). Looking at the coronary stent market, Grennan finds that differences in bargaining ability accounts for 79 percent of the variation in prices across hospitals. Id. at 3018. Also, as detailed below, litigation involving patent infringement and damages can involve assessments over the relative levels of bargaining power in order to make predictions about counterfactual bargaining outcomes. See infra Part III.

42. Although, one concern is that the relative levels of bargaining power could conceivably influence the magnitude of the price prediction.

43. See Oliver E. Williamson, Antitrust Economics: Mergers, Contracting, And STRATEGIC BEHAVIOR 28 (1987) ("Although this haggling is jointly (and socially) unproductive, it constitutes a source of private pecuniary gain. Being, nevertheless, a joint profit drain, an incentive to avoid these costs, if somehow this could be arranged, is set up.").

44. See Ariel Rubinstein, Perfect Equilibrium in a Bargaining Model, 50 ECONOMETRICA 97 (1982).

45. See id.

46. See id.

47. See Richard E. Kihlstrom et al., Risk Aversion and Nash's Solution to the Bargaining Problem, in MATHEMATICAL ECONOMiCs And Game THEORY (Otto Moeschlin \& Rudolf Henn eds., 1981); Roth \& Rothblum, supra note 25, at 639-47. 
the "status quo" or "disagreement point." 48 The intuition is that the parties' payoff from not agreeing to a deal influences the price of the actual deal. ${ }^{49}$ Outside options matter. Nash explicitly incorporated the outside option into the utility function and optimization; however, we illustrate the concept using a more basic approach.

Returning back to $V_{B}$ and $V_{S}$ to denote the buyer's maximum and seller's minimum valuation, respectively, from the deal, we can model changes in the outside option through changes in the valuation itself. For instance, suppose that the seller, let us say an employee at a firm, receives a better outside offer for employment, where $V_{S}^{\prime}>V_{S}$. This shrinks the joint surplus range; thus, $G^{\prime}<G$. Although the joint surplus has shrunk, it has a higher minimum due to the better outside option. Assuming equal bargaining power, this will result in a higher price (or wage in our example). Conversely, if the buyer no longer values the deal as highly (e.g., an employer could outsource some of their workers' responsibilities offshore), then this will again shrink the gains from trade, and it will result in a lower price, all else remaining equal. What this approach tells us is that, the more that a buyer values a transaction, the more likely the price will be higher. Conversely, the less options that a seller has-or similarly, the lower its marginal cost - then the more likely the price will be lower. The value of the outside option is a central result of Nash's seminal work and remains the bedrock of bargaining models. It is the fuel to the predictions of bargaining models used in merger analyses.

To more explicitly make the point in the context of media content creators and downstream content distributors, such as a streaming video service, suppose a buyer has an initial valuation of $\$ 10$ per subscriber to engage in a deal to carry the seller's content on the buyer's streaming video service. Let us further assume the seller must receive a price of $\$ 2$ to cover its cost. We would expect a price of $\$ 6$ if the surplus is split evenly. Now suppose that the buyer has another option to carry a channel very similar to the seller's and has an offer on the table for $\$ 8$ per subscriber from that alternative. Now, the buyer is only willing to pay up to $\$ 8$, so the range of prices to provide a mutually beneficial exchange has shrunk. The price will fall to \$5-again, assuming an equal split of the surplus. The idea is that if there are a multitude of close substitutes, then the value of the outside option is relatively high. Consequently, the buyer or seller does not feel a strong need to engage in a particular transaction at unfavorable terms.

48. See Ken Binmore et al., The Nash Bargaining Solution in Economic Modelling, 17 RAND J. ECON. 176, 176 (1986).

49. Id. 
A key point made by Schelling is that strategy "is not concerned with the efficient application of force but with the exploitation of potential force." 50 Thus, often the whole point is not whether a stick is actually yielded but the size and threat of the stick. This is the point picked up by critics of the district court judge, Judge Richard Leon, in United States $v$. AT\& T Inc. ${ }^{51}$ The criticism is that Judge Leon did not understand a central premise of bargaining models when he stated it was unlikely that AT\&T would ever engage in a blackout because there had been no history of a long-term blackout. ${ }^{52}$ This is certainly a tempting critique because Judge Leon focused on the actual application of force rather than the potential exploitation of force, which is contrary to the key feature of bargaining models aptly described by Thomas Schelling. ${ }^{53}$

In sum, bargaining leverage and how it changes, typically via a merger or through alleged anticompetitive conduct, is the central feature of antitrust bargaining models. It is the primary engine that drives the anticompetitive price increase predictions. The fundamental point is that changes in bargaining leverage are relevant regardless of whether the core antitrust allegation is horizontal or vertical, but there are differences between these two frameworks. In the following sections, we provide an overview of bargaining models generally used to model horizontal mergers between hospitals and to model vertical mergers between video content providers and distributors.

\section{B. Bargaining Models for Horizontal Mergers: Hospitals}

After eight straight failed challenges to hospital mergers in federal court between 1994 and 2001, the FTC changed its economic approach and methods to analyze hospital mergers. ${ }^{54}$ Highly influential research that fueled this new approach includes works of Robert Town and Gregory

50. Thomas C. Schelling, The Strategy of Conflict 5 (1960).

51. 310 F. Supp. 3d 161 (D.D.C. 2018), aff'd, 916 F.3d 1029 (D.C. Cir. 2019).

52. See, e.g., Steven C. Salop, The AT\&T/Time Warner Merger: How Judge Leon Garbled Professor Nash, 6 J. ANTITRUST ENFORCEMENT 459, 463 (2018) ("Judge Leon understood that blackout threats are made in the context of programmer/distributor negotiations, referring to them as part of a 'Kabuki dance'. He also noted that they often try to determine the costs of a blackout. However, he nonetheless was skeptical [sic] of the bargaining leverage model because leverage is calculated on the assumption that failure to reach agreement would lead to a permanent blackout of the content being negotiated. This conclusion also involves an erroneous analysis of bargaining theory. The fact that permanent blackouts [sic] rarely if ever occur is not inconsistent with leverage theory. The leverage theory is premised on blackout threats, not actual blackouts.").

53. See id.; see also SCHELling, supra note 50.

54. See Keith Brand \& Christopher Garmon, Hospital Merger Simulation, AM. HEALTH LAw. Ass'N, Jan. 2014, at 1, 1-2. 
Vistnes, and Cory Capps et al. ${ }^{55}$ The core intuition of Town and Vistnes's bargaining model is premised on post-merger changes in bargaining leverage. ${ }^{56}$ Specifically, when two hospitals merge, the primary change to the bargaining situation - as it applies to the negotiation between the hospitals and insurance providers, i.e., managed care organizations (MCOs) - is that the merger will reduce the available substitutes to the MCOs if the bargain breaks down. ${ }^{57}$ In other words, the merged entity is more of a "must have" set, or bundle, of hospitals because there are less substitutes available to insurance providers, which reduces the threat point of MCOs. ${ }^{58}$ This assumes that hospitals negotiate in an "all-or-nothing" manner with MCOs and, consequently, only offer their system of hospitals as a single set rather than a la carte. ${ }^{59}$ This is a standard assumption; although, there are approaches that do not require an all-or-nothing bargaining position. ${ }^{60}$

Further, an MCO's post-merger bargaining leverage is determined by the impact on the MCO's profit from (i) excluding a given hospital and (ii) including the next best substitute hospital. Therefore, the more important a given set of hospitals are for an MCO's revenues, the more bargaining leverage those hospitals will have. ${ }^{61}$ While the conceptual idea is straightforward, an empirical strategy is needed to actually make postmerger price predictions from the change in bargaining leverage. Town and Vistnes, and Capps et al. both adopt the willingness-to-pay (WTP) approach. ${ }^{62}$ At its core, WTP measures the value that a particular hospital brings to an $\mathrm{MCO}$, which is a derived demand from potential and actual patients. The data requirements to estimate WTP and post-merger changes in WTP involve patient-level inpatient discharge data, data on the merging

55. Robert Town \& Gregory Vistnes, Hospital Competition in HMO Networks, 20 J. HEALTH ECON. 733, 733-53 (2001); Cory Capps et al., Competition and Market Power in Option Demand Markets, 34 RAND J. ECON. 737, 737-63 (2003).

56. Town \& Vistnes, supra note 55, at 736 ("A hospital's bargaining leverage with an HMO depends on the HMO's alternatives to contracting with that hospital: the less profitable those alternatives, the greater the hospital's bargaining power and the higher the price it can set.").

57. Id.

58. Id.

59. Id.

60. See, e.g., Deborah Haas-Wilson \& Christopher Garmon, Two Hospital Mergers on Chicago's North Shore: A Retrospective Study 8-10 (FTC Bureau of Econ., Working Paper No. 294, 2009); Garmon, supra note 10, at 1097.

61. Brand \& Garmon, supra note 54, at 5. The threat point for a set of hospitals "can be defined as the price at which its incremental profit under the agreement equals the profit associated with status as an 'out-of-network' provider." Id. While the MCO's threat point "can be defined as the price at which its profit under the agreement equals the profits it would earn marketing a network that does not include the hospital." Id.

62. See sources cited supra note 55 . 
hospitals as well as potential rivals, and hospital cost data. ${ }^{63}$ The goal is to use market-based data to capture the "value" that a particular hospital provides to patients in the surrounding area. With estimates of WTP in hand, economists can then simulate the effect of a merger on prices.

Importantly, the use of bargaining models is not the only approach to estimating competitive effects from hospital mergers. Economists can also use a standard differentiated Bertrand model of competition. ${ }^{64}$ This structural approach was used by the FTC in its recent challenge of Advocate-North Shore in Illinois. ${ }^{65}$ Grennan notes that the differentiated Bertrand model is a special case of Nash bargaining where bargaining power is assumed to reside completely with the seller-in this case hospitals - and there is no price discrimination. ${ }^{66}$ In the following section, we will note a parallel situation for bargaining models used for vertical mergers, where the vertical GUPPI is a special case of Nash bargaining where bargaining power is assumed to reside completely with the seller, in that case video content creators.

Whether using the WTP or the structural approach, the degree to which a merger impacts pricing is effectively the degree to which the merging parties are considered substitutes, which is determined by consumer preferences based on characteristics of the merging and alternative hospitals. ${ }^{67}$ Thus, even within a bargaining context, the assessment of a horizontal merger inevitably comes down to the closeness of substitutes between the two parties. ${ }^{68}$ The degree to which the relative bargaining leverage shifts post-merger, however, is clearly dependent on the size of the diversion ratio between the merging parties, to rivals, and to the outside good, i.e., all products outside of the relevant set of products

\section{Id.}

64. See Martin S. Gaynor et al., A Structural Approach to Market Definition with an Application to the Hospital Industry, 61 J. INDUS. ECON. 243 (2013).

65. See Steven Tenn \& Sophia Vandergrift, Geographic Market Definition in Urban Hospital Mergers: Lessons from the Advocate-NorthShore Litigation, ANTITRUST SOURCE, Dec. 2017, at 1, 1.

66. See Matthew Grennan, Price Discrimination and Bargaining: Empirical Evidence from Medical Devices, 103 AM. ECON. REV. 145, 160 (2013) ("[W]hen the hospital [in this setting the buyer] has zero bargaining ability ... manufacturers [of medical devices] set prices in a BertrandNash price equilibrium; and when a manufacturer has zero bargaining ability ... that manufacturer prices at cost.").

67. See, e.g., U.S. Dep'T of Justice \& Fed. Trade Comm'N, Commentary on the HORIZONTAL MERGER GUIDELINES 35 (2006) ("For example, close head-to-head competition between two hospitals allows an MCO credibly to threaten both that it will contract with, and steer its patients to, only the other. The elimination of such competition through a merger, therefore, can enable the hospitals to negotiate higher prices."); Garmon, supra note 10, at 1076 ("Whether the post-merger negotiations are collective or separate, both of the merger effects are driven by the potential diversion between the merging hospitals, which is a measure of the substitutability of the hospitals in the eyes of the MCO's members.").

68. Garmon, supra note 10, at 1076. 
under consideration. ${ }^{69}$

\section{Bargaining Models for Vertical Mergers and Vertical GUPPIs}

The DOJ in both the Comcast-NBCU and AT\&T-Time Warner matters used the same basic axiomatic approach to the bargaining framework-where "axiomatic" refers to modeling the outcome of the process rather than the actual mechanics of the negotiations. ${ }^{70}$ These models are considered strategic bargaining models. ${ }^{71}$ The two negotiating sides are the upstream content providers, i.e., channels, and the downstream content distributors, i.e., MVPDs, and the negotiations are over the per-subscriber-per-month (PSPM) fee or price. Focusing on the AT\&T-Time Warner matter, the government expert, Dr. Carl Shapiro, assumes that the two sides will split the joint surplus evenly and, thus, the price is determined by the Buyer's Maximum price $\left(V_{B}\right)$ and the Seller's Minimum price $\left(V_{S}\right){ }^{72}$ If the gains $(G)$ from trade is given by $G=V_{B}-$ $V_{S}$, the equilibrium price will be where the gains from trade are equally split: $P_{\text {pre }}^{*}=\frac{1}{2}\left(V_{B}+V_{S}\right)$. If the merger increases the seller's minimum price to $V_{S}^{\prime}$ where $V_{S}^{\prime}>V_{S}$, then $P_{\text {post }}^{*}=\frac{1}{2}\left(V_{B}+V_{S}^{\prime}\right)$ where $P_{\text {post }}^{*}>$ $P_{p r e}^{*}$. More precisely, the increase in price is $\Delta P=\frac{1}{2}\left(V_{S}^{\prime}-V_{S}\right)$. This is the central basis as to how a better outside option increases the predicted price. $^{73}$

Why would the seller's outside option be better post-merger? The core intuition is that, post-merger, a combined AT\&T-Time Warner has a higher opportunity cost from striking a deal with downstream competitors such as Dish Network. Before the merger, if Time Warner struck a deal with Dish Network, then the full costs and benefits of the deal are "internal" to Time Warner. However, post-merger, a deal with Dish Network actually causes a negative externality onto the larger AT\&T

69. Brand \& Garmon, supra note 54, at 3 n. 6 (noting that diversion ratio is conventionally measured as the percentage of lost output that flows from one product to another after a marginal increase in price, but that in the context of hospitals patients generally "pay" through insurance, and concluding, "[i]n hospital markets, if marginal changes in prices do not affect admission patterns, the diversion ratio from hospital $\mathrm{A}$ to hospital $\mathrm{B}$ is defined as the expected share of volume (e.g., discharges) captured by hospital B if hospital A is excluded from a network").

70. For more on this distinction, see Gregory J. Werden \& Luke M. Froeb, Unilateral Competitive Effects of Horizontal Mergers II: Auctions and Bargaining, in 2 ISSUES IN COMPETITION LAW AND POLICY 1343 (Wayne Dayle Collins et al. eds., 2008).

71. Id.

72. See Shapiro Report, supra note 37, at 41.

73. See, e.g., id. at 46 ("The Nash Bargaining model predicts that the Turner fees paid by Dish will rise because AT\&T's post-merger Seller Min for the Turner Content licensed to Dish will be higher than Time Warner's pre-merger Seller Min for the Turner Content licensed to Dish.”). 
corporation - outside of the Time Warner division - since it hurts AT\&T's DirecTV product which competes with Dish Network. Alternatively, a combined AT\&T-Time Warner is harmed less if it does not strike a deal with Dish Network because the loss in licensing revenues is mitigated by some Dish Network customers switching over to DirecTV, which clearly benefits the combined entity. Critical to Dr. Shapiro's model is the assumption that the Seller's Minimum price is based on a blackout. ${ }^{74}$

Even if the economic profit from a blackout changes post-merger, the question becomes "how much?" The primary variables needed to make this calculation are the margins at DirecTV; the elasticity of demand at rival MVPDs if they lose Turner Network content; and the diversion ratio from rival MVPDs to DirecTV. ${ }^{75}$ The precise formula for the price increase is given in Dr. Shapiro's Report, Appendix G, equation 19: ${ }^{76}$

$$
\Delta w_{i} \equiv w_{i}^{*}-w_{i}=(1-\alpha)\left(p_{d}-c_{d}-w_{d}\right) \gamma_{i d} \bar{L}
$$

In the above formula, $\Delta w_{i}$ is the post-merger change in the price to a rival such as Dish Network; $\alpha$ is the Nash bargaining power parameter that is assumed to be $1 / 2 ;\left(p_{d}-c_{d}-w_{d}\right)$ is the margin that AT\&T gets at DirecTV per subscriber; $\gamma_{i d}$ is the diversion ratio from Dish Network to DirecTV; and $\bar{L}$ is the constant annual subscriber loss rate from Dish Network. Thus, the price prediction effectively comes down to margins, diversions, and demand elasticity. ${ }^{77}$

Similarly, in the Comcast-NBCU matter, the FCC's bargaining model was based primarily on a post-merger change in the opportunity cost of the merged firm continuing to supply the downstream rival. ${ }^{78}$ In 2009, the Comcast Corporation announced the acquisition of NBC Universal (NBCU). ${ }^{79}$ The vertical part of the deal involved combining Comcast's cable services with NBCU's suite of channels. ${ }^{80}$ As a forerunner to the model used in the AT\&T-Time Warner matter, the FCC derived the following predicted increase in programming price due to the merger: ${ }^{81}$

$$
\Delta w=(1-\alpha) m \gamma L
$$

In the above formula, $\Delta w$ is the post-merger change in the price to

\footnotetext{
74. Id. at 126 .

75. Id. at $49-50$.

76. Id. at 137 (app. G, equation 19).

77. Id. at 136 .

78. See Rogerson, supra note 37.

79. See, e.g., Tim Arango \& Brian Stelter, Comcast Receives Approval for NBC Universal Merger, N.Y. TIMES (Jan. 19, 2011), https://www.nytimes.com/2011/01/19/business/media/19 comcast.html [https://perma.cc/BB5F-2SGT].

80. These channels included, inter alia, NBC, USA, SyFy, MSNBC, CNBC, and Bravo.

81. The formula is from Rogerson, supra note 37, equation 4. The notation has been slightly changed to more closely match Dr. Shapiro's notation in AT\&T-Time Warner; see also Shapiro Report, supra note 37, at 41.
} 
rivals to Comcast; $\alpha$ is the Nash bargaining power parameter that is assumed to be $1 / 2 ; m$ is the profit margin that Comcast gets per subscriber; $\gamma$ is the diversion ratio from competitors to Comcast; and $L$ is the departure rate from rivals if NBCU content became unavailable. Again, the price prediction effectively comes down to margins, diversions, and demand elasticity when content becomes unavailable.

Note that both the AT\&T-Time Warner and Comcast-NBCU matters involved a consideration of a second theory of harm, which is that postmerger, the integrated vertical entity would have the incentive and ability to completely foreclose - either temporarily or permanently-MVPDs. ${ }^{82}$ This theory of harm can easily be folded into the bargaining framework. If the integrated firm's profit from foreclosure $\left(\pi_{F}^{\text {post }}\right)$ is greater than the profit from the post-merger anticipated bargaining outcome $\left(\pi_{P *}^{\text {post }}\right)$, then the integrated firm will foreclose rival MVPDs.

In essence, accepting the vertical bargaining models presented by federal agencies in recent court decisions is the same as accepting that all vertical mergers with similar structural conditions as the AT\&T-Time Warner and Comcast-NBCU matters have a gross upward pricing pressure. As Gopal Das Varma and Martino De Stefano state, "[a]ll three numbers [margins, diversions, and departure rate] are typically positive. The technique is, thus, hardwired to predict a wholesale price increase." ${ }^{\prime 33}$ This echoes the framework advanced by Steven Salop and Serge Moresi, in which they developed a number of vertical gross upward pricing pressure indices (vGUPPIs). ${ }^{84}$ Like its horizontal counterpart, ${ }^{85}$ vGUPPIs are intended to provide a measure of pricing "pressure," i.e., the strength of the incentive, to raise price, although it is not necessarily a price prediction per se. ${ }^{86}$ The framework involves the calculation of three indexes. ${ }^{87}$ The first index is vGUPPIu, which is the pricing incentive of the upstream firm. ${ }^{88}$ The informational requirements are primarily the diversion ratio from the upstream firm to the downstream firm and the

82. See Rogerson, supra note 37, at 540; see also Shapiro Report, supra note 37, at 86-87.

83. Varma \& De Stefano, supra note 10.

84. Serge Moresi \& Steven C. Salop, vGUPPI: Scoring Unilateral Pricing Incentives in Vertical Mergers, 79 ANTITRUST L.J. 185 (2013).

85. See U.S. Dep'T Of Justice \& Fed. Trade Comm'N, Horizontal Merger Guidelines 2021 (2010), https://www.ftc.gov/system/files/documents/public_statements/804291/100819hmg.pdf [https://perma.cc/A4C7-4DTQ].

86. See generally Moresi \& Salop, supra note 84. Although, price predictions can be made under certain assumptions regarding the shape of the demand curve.

87. Id. at 191 .

88. Id. at $192-95$. 
downstream margin of the merging firm. ${ }^{89}$ The vGUPPIu will always be a positive number (assuming nonzero values for margins and diversions) and the most analogous to the prediction of bargaining models of an increase in the upstream firm's price to downstream rivals. ${ }^{90}$ The second index is vGUPPIr, which is the pricing incentive of the downstream rival. ${ }^{91}$ The primary informational requirement is the pass-through rate of the upstream firm's cost changes on downstream prices. ${ }^{92}$ Again, vGUPPIr will be a positive number with the intuition that a higher input price to rivals will cause them to raise their own prices to consumers. ${ }^{93}$ The final index is vGUPPId, which is the pricing incentives of the downstream merging firm. ${ }^{94}$ The informational requirements are primarily the diversion ratio from the downstream firm to the upstream firm and the upstream margin. ${ }^{95}$ Notwithstanding the downward pricing pressure from the elimination of double marginalization (EDM), the vGUPPId will also be positive since a price increase by the integrated firm's downstream unit, e.g., DirecTV, will benefit the upstream unit, i.e., Turner Network, because it will lead to an increase in sales to rivals due to diverted sales. ${ }^{96}$

In sum, both bargaining models (for vertical mergers) and vGUPPIs effectively take departure rates, diversion ratios, and relative margins into account to simulate the incentive to engage in a strategy to raise rivals' costs. This makes the two approaches very close cousins. A critical difference, however, is that the vGUPPI framework assumes that "manufacturers have no bargaining power over input prices", 97 in other words, all the bargaining power lies with the upstream input supplier. Moreover, the vGUPPI indicia are arguably more "complete" in that they account for more potential post-merger pricing effects - namely from the integrated downstream unit and rivals to that unit. Thus, what vGUPPIs are to bargaining models for vertical media mergers are analogous to what standard differentiated Bertrand models of competition are to bargaining models for horizontal hospital mergers.

89. See id. The diversion ratio from the upstream firm to the downstream firm is closely related to the diversion ratio between the downstream rival (e.g., Dish) to the firms' downstream firm (e.g., DirecTV).

90. See id.

91. Id. at 195-97.

92. See id.

93. See id.

94. Id. at 197-99.

95. See id. The diversion ratio from the downstream firm to the upstream firm is again closely related to the diversion ratio between the downstream rival (e.g., Dish) to the firms' downstream firm (e.g., DirecTV).

96. See id.

97. Id. at app. n.1, https://www.americanbar.org/content/dam/aba/publishing/antitrust_law journal/at_alj_moresi_salop.pdf[https://perma.cc/8GE2-F4TK]. 


\begin{tabular}{|c|c|c|}
\hline & $\begin{array}{c}\text { Equal Bargaining } \\
\text { Power } \\
\left(\alpha=\frac{1}{2}\right)\end{array}$ & $\begin{array}{c}\text { All Bargaining Power } \\
\text { Resides with the } \\
\text { Seller } \\
(\alpha=1)\end{array}$ \\
\hline $\begin{array}{c}\text { Horizontal } \\
\text { Hospital } \\
\text { Mergers } \\
\end{array}$ & $\begin{array}{c}\text { Willingness-to-Pay } \\
\text { (WTP) Bargaining Model }\end{array}$ & Differentiated Bertrand \\
\hline $\begin{array}{l}\text { Vertical Media } \\
\text { Mergers }\end{array}$ & $\begin{array}{c}\text { Comcast-NBCU \& } \\
\text { AT\&T-Time Warner } \\
\text { Bargaining Model }\end{array}$ & vGUPPIs \\
\hline
\end{tabular}

\section{Comparing Bargaining Models for Horizontal and Vertical Mergers}

Before turning to how courts have received and interpreted economic bargaining models in various contexts, we briefly compare and contrast the WTP bargaining models used for hospital cases and the bargaining models used in the Comcast-NBCU and AT\&T-Time Warner matters. The most important similarity is that both involve a post-merger change in bargaining leverage, which is the genesis for the predicted post-merger price increase. For hospital mergers, the bargaining change is analogous to having a better bundle of products with more hospitals in the offer setassuming "all-or-nothing" bargaining. This reduces the set of outside options (in terms of substitute hospitals) for MCOs, which increases the bargaining leverage of the merging hospitals. This allows the hospitals to extract more of the bargaining surplus post-merger. For media mergers, the bargaining change is that higher input prices to downstream rivals can result in an additional benefit to the integrated firm in the form of greater sales to the newly acquired downstream unit (due to diverted sales). In other words, it is posited that the opportunity cost of dealing with downstream rivals has increased post-merger.

Thus, while both types of models share the same change in bargaining leverage, they differ as to why the leverage changes and how that change manifests into a price increase. For horizontal hospital mergers, it is due to the standard antitrust result that the acquisition of a close substitute affords the merged entity greater market power. For vertical media mergers, it is due to the calculation that the total profits over the entire set of complementary goods in a value chain are higher with a higher postmerger price. 


\section{USE OF BARGAINING MODELS IN ANTITRUST CASES}

The use of bargaining models in antitrust matters essentially comes down to comparing counterfactuals, as it does with all models of competition. For horizontal mergers, the foundational change is that the merged entity now internalizes some of the sales loss if it raises price(s) on one or both of the products - assuming some positive level of diversion between them. ${ }^{98}$ For vertical mergers, the vertically integrated firm now owns complementary assets at two or more levels of the supply chain.

In this Part, we review a number of recent cases involving judicial assessments of bargaining models, focusing on how courts have adjudicated these issues. Broadly, the courts' inquiries follow a typical pattern. First, does the proposed bargaining model capture the full flavor and contours of a particular market? Second, are there reliable sources for the inputs needed to generate predictions from the model? Third, is there some external validity to the predictions in terms of actual market-based evidence?

Ultimately, we generally find that courts struggle with applying the abstractions of bargaining models to the facts particular to their case. Moreover, courts are reticent to adopt the predictions from these models without some other evidence to validate the predictions. While abstractions are inherent to all economic models to one degree or another, the level involved with axiomatic bargaining models (i.e., bargaining models that do not model the actual mechanics of the bargaining process but rather arrive at a prediction through properties that the equilibrium must satisfy) and their primary focus on measuring changes in bargaining leverage have left the courts uncertain as to their predictive merits. This does not mean, however, that all courts reject the models. Particularly for hospital mergers, judges have embraced the models as standard and reliable analyses. However, particularly for vertical media mergers, their acceptance has been significantly more uneven.

Below, we review the use of bargaining models in seven cases running from 2010 through 2018. The first three, VirnetX Inc. v. Cisco Systems, Inc., Limelight Networks, Inc. v. XO Communications, LLC, and FTC v. Qualcomm, Inc., involve patent royalty disputes where the court is asked to determine the counterfactual bargaining outcome. ${ }^{99}$ The fourth case, FTC v. Advocate Health Care, is the most recent hospital merger that has

98. Alternatively, the merged entity could discontinue one of the merged products. This is just a special case where the price increase on the discontinued product is infinite.

99. VirnetX Inc. v. Cisco Sys., Inc., 767 F.3d 1308, 1313 (Fed. Cir. 2014); Limelight Networks, Inc. v. XO Commc'ns, LLC, No. 3:15-CV-720-JAG, 2018 WL 678245 (E.D. Va. Feb. 2, 2018); FTC v. Qualcomm, Inc., 411 F. Supp. 3d 658 (N.D. Cal. 2019). 
been challenged in court. ${ }^{100}$ The last three cases, Laumann $v$. National Hockey League, Behrend v. Comcast, and AT\&T, ${ }^{101}$ involve media markets and bargaining between the upstream content suppliers and downstream content distributors. ${ }^{102}$

\section{A. VirnetX, Inc. v. Cisco Systems, Inc.}

In Virnet $X$, although the Federal Circuit did not directly invoke an antitrust issue, the case involved assessment of a reasonable royalty rate from a patent infringement dispute between VirtnetX, the patent holder, and Cisco and Apple, the alleged patent infringers. ${ }^{103}$ Central to this assessment was whether a Nash bargaining model was a reliable and appropriate framework to estimate the royalty rate. ${ }^{104}$ Specifically, the issue was whether the Nash bargaining assumption of a 50/50 split was a reliable starting point for the bargaining solution. ${ }^{105}$ At trial, VirtnetX's damages expert, Roy Weinstein, offered various approaches to calculate a reasonable royalty rate, which the district court had admitted over Apple's Daubert motion to dismiss the testimony. Under one of the approaches, Weinstein testified that "the parties [would have] split between themselves the incremental or additional profits that are associated with the use of the patented technology." 106 As the appellate judge further explained, "[w]ithout examining the applicability to this case of all the preconditions for the Nash Bargaining Solution," Weinstein "modified that result by $10 \%$, explaining that VirnetX would have received only $45 \%$ of the profit because of its weaker bargaining position, leaving 55\% for Apple."107

In deciding on the admissibility of the Nash bargaining model and solution, the court cited a number of district court cases that rejected the 50/50 Nash bargaining power assumption. ${ }^{108}$ Nonetheless, the court also cited a number of cases that had admitted the 50/50 Nash bargaining solution under various rationales, including, that it was used only "as a

100. FTC v. Advocate Health Care, No. 15C11473, 2017 WL 1022015 (N.D. Ill. Mar. 16, 2017).

101. Laumann v. Nat'l Hockey League, 117 F. Supp. 3d 299 (S.D.N.Y. 2015); Behrend v. Comcast Corp., 264 F.R.D. 150 (E.D. Pa. 2010); United States v. AT\&T, Inc., 310 F. Supp. 3d 161, 164 (D.D.C. 2018), aff'd, 916 F.3d 1029 (D.C. Cir. 2019).

102. We do not discuss Comcast-NBCU because the matter was settled before a court decision.

103. VirnetX, Inc. v. Cisco Sys., Inc., 767 F.3d 1308, 1313 (Fed. Cir. 2014).

104. Id. at 1325 .

105. Id.

106. Id.

107. Id.

108. Id. at 1331-32; see also Robocast, Inc. v. Microsoft Corp., No. 10-1055-RGA, 2014 WL 350062 (D. Del. Jan. 29, 2014); Dynetix Design Sols. v. Synopsys, Inc., No. C11-5973, 2013 WL 4538210 (N.D. Cal. Aug. 22, 2013); Oracle Am., Inc. v. Google Inc., 798 F. Supp. 2 d 1111 (N.D. Cal. 2011). 
check" to other analyses, that it was applicable to the specific facts of the case, and that defendants had not challenged its admissibility. ${ }^{109}$ Ultimately, the court rejected the Nash bargaining solution and found it inadmissible under Daubert to approximate a reasonable royalty rate for a hypothetical negotiation. ${ }^{10}$ This rejection was central to the court's decision to vacate the damages award and remand the case for further proceedings. ${ }^{111}$ The court's primary rationale was that the:

Nash theorem arrives at a result that follows from a certain set of premises. It itself asserts nothing about what situations in the real world fit those premises. Anyone seeking to invoke the theorem as applicable to a particular situation must establish that fit, because the 50/50 profitsplit result is proven by the theorem only on those premises. ${ }^{112}$

\section{B. Limelight Networks, Inc. v. XO Communications, LLC}

In Limelight Networks - a case with parallels to VirnetX, but with an important difference - two parties, Limelight and Akamai, were involved in a patent infringement suit where "they cross-allege[d] patent infringement violations based on their competing products." ${ }^{113}$ Each party provided an economic expert to calculate damages. ${ }^{114}$ Plaintiff's expert, Dr. Stephen Prowse, attempted to present a reasonable royalty estimation for Limelight's patents by "creating a hypothetical negotiation between the parties to estimate what Akamai would have negotiated to pay Limelight for a license on the patents instead of infringing." 115 Rather than using the Nash bargaining power assumption of 50/50 as a starting point, however, Prowse used the bargaining model developed by Rubinstein, ${ }^{116}$ which involves assessing the relative patience of each party in a negotiation to determine how a surplus is ultimately split. ${ }^{117}$ Prowse used "each company's weighted average cost of capital (WACC) as a proxy for

109. VirnetX, 767 F.3d at 1332; see also Mformation Techs., Inc. v. Research in Motion Ltd., No. C08-04990, 2012 WL 1142537, at *3 n.19 (N.D. Cal. Mar. 29, 2012); Gen-Probe Inc. v. Becton Dickinson \& Co., No. 09-CV-2319, 2012 WL 9335913, at*3 n.3 (S.D. Cal. Nov. 26, 2012); SanofiAventis Deutschland GMBH v. Glenmark Pharm. Inc., No. 07-CV-5855, 2011 WL 383861, at *13 (D.N.J. Feb. 3, 2011); Amakua Dev. LLC v. Warner, No. 05C3082, 2007 WL 2028186, at *20 (N.D. Ill. July 10,2007$)$.

110. Virnet $X, 767$ F.3d at $1332-34$.

111. Id. at 1334.

112. Id. at 1332 .

113. Limelight Networks, Inc. v. XO Commc'ns, LLC, No. 3:15-CV-720, 2018 WL 678245, at *4 (E.D. Va. Feb. 2, 2018).

114. Id. at $* 2$.

115. $I d$.

116. Id. at *2-3.

117. Rubinstein, supra note 44 , at 97. 
each party's relative patience." 118 This is particularly noteworthy because the WACC is also what the DOJ's expert, Dr. Carl Shapiro, used in the AT\&T-Time Warner matter to measure relative levels of patience. ${ }^{119}$

Judge John Gibney was unconvinced, however, and stated that "Prowse's method is simply fancy guesswork."120 Echoing the rationale of the Virnet $X$ court, Judge Gibney explained that the bargaining model "contain[ed] almost no basis in facts relevant to this case,"" he reasoned that " $[\mathrm{u}] \operatorname{sing}$ WACC as a proxy for patience in the Rubinstein model does not consider the actual stakes in the hypothetical negotiation or even the specific patents negotiated." 122 The judge further emphasized that the issue was not whether Prowse chose the right or wrong WACC measure, but whether the WACC measure was relevant at all to inform a jury on "how the parties would negotiate over these patents." 123

C. FTC v. Qualcomm, Inc.

In Qualcomm, the FTC alleged that Qualcomm engaged in anticompetitive practices to raise its royalty rates for its standard essential patents (SEPs) above a fair, reasonable, and nondiscriminatory (FRAND) rate and that Qualcomm anticompetitively excluded rivals through use of exclusive contracts. ${ }^{124}$ At the heart of the FTC's case are two licensing policies that Qualcomm historically has used to license its SEPs. ${ }^{125}$ First, Qualcomm has a "no license, no chips" policy. ${ }^{126}$ Qualcomm will not sell its modem chipsets, which are used to send data between the mobile devices and the cellular network, to mobile device original equipment manufacturers (OEMs), such as Apple and Samsung, without first having a royalty agreement in place for its SEPs. ${ }^{127}$ The rationale is that the SEPs

118. Limelight Networks, 2018 WL 678245, at*3.

119. See Shapiro Report, supra note 37, at 42 ("In practice, the relative discount rates can be approximated by a relative measure of the cost of capital for the two negotiating parties. Indeed, when I follow industry practice, and use the weighted average cost of capital ('WACC') to approximate the discount rates of different MVPDs, I find that AT\&T and any of its rival MVPDs would split the gains from trade equally or nearly equally."). Here, Shapiro is using both the Nash bargaining assumption of a 50/50 split and a Rubinstein framework to validate that assumption.

120. Limelight Networks, 2018 WL 678245, at*3.

121. Id.

122. Id.

123. Id.

124. FTC v. Qualcomm Inc., 411 F. Supp. 3d 658, 669 (N.D. Cal. 2019).

125. Id. at 671-72.

126. Id. at 703 .

127. Id. at 675 . 
cover the intellectual property embodied in the chipsets. ${ }^{128}$ Second, Qualcomm only licenses its SEPs to device-level OEMs rather than rival component-level chipset suppliers. ${ }^{129}$ A central justification for this industry-wide approach to licensing at the device-level, rather than the component-level, is that it undoubtedly minimizes transaction costs. ${ }^{130}$

The FTC alleged that these licensing policies allowed Qualcomm to "tax" rival chipset suppliers - i.e., effectively engage in a margin squeeze (although, the FTC appears to take great pains to avoid this label). ${ }^{131}$ The mechanism of the harm is that the "no license, no chips" policy allows Qualcomm to obtain supra-FRAND royalty rates for its SEPs. ${ }^{132}$ OEMs do not challenge the supra-FRAND rates in arbitration because of Qualcomm's bargaining leverage. ${ }^{133}$ The thought is that if OEMs challenge the royalty rates, then Qualcomm will withhold its chipsets; as a result, the OEMs would be unable to ship their mobile devices. ${ }^{134}$ To avoid this undesired outcome, the OEMs simply pay the supra-FRAND rates. ${ }^{135}$ In turn, this "taxes" Qualcomm's chipset rivals because OEM margins are squeezed by the elevated royalties and, consequently, OEMs demand lower chipset prices from rivals. ${ }^{136}$ Since chipset rivals do not have the lucrative supra-FRAND royalties like Qualcomm to subsidize their operations, these rivals are unable to compete because, effectively, their margins are squeezed. ${ }^{137}$

This tax theory emerges from the bargaining model developed by the FTC's economic expert, Dr. Carl Shapiro, which is similar to the increased-leverage theory advanced by Dr. Shapiro and the DOJ in the AT\&T-Time Warner matter. ${ }^{138}$ The general idea is that a company that operates two complementary business units can leverage market power in

\footnotetext{
128. More specifically, rather than "bundling" the actual physical components of the modem chipset with the intellectual property into a "single price," Qualcomm separately negotiates the price for the modem chipset and the royalties for the intellectual property that is used in the modem chipset. Id. at 713 .

129. Id. at 755 .

130. By licensing at the device-level, it allows SEP holders such as Qualcomm, Nokia, and Ericsson to negotiate with only one party rather than multiple parties throughout the supply chain, and, importantly, it avoids the technically difficult and often infeasible exercise of determining which SEP goes to which level of the supply chain.

131. See Lindsey M. Edwards, Douglas H. Ginsburg \& Joshua D. Wright, Section 2 Mangled: FTC v. Qualcomm on the Duty to Deal, Price Squeezes, and Exclusive Dealing (Geo. Mason Univ. Law \& Econ. Research Paper Series, Research Paper No. 19-21, 2019).

132. Id. at $15-16$.

133. Id.

134. Id.

135. Id.

136. Id.

137. $I d$.

138. United States v. AT\&T, Inc., 916 F.3d 1029, 1035 (D.C. Cir. 2019).
} 
one division over its customers in the second division, to the detriment of both the customers and its competitors. ${ }^{139}$ In Qualcomm, the FTC alleged that Qualcomm used its market power over premium chipsets to impose increased royalty rates in licensing agreements for its SEPs, which reduced the OEMs' willingness to pay for chips from Qualcomm's rivals. ${ }^{40}$

Qualcomm's economic expert, Dr. Aviv Nevo, testified that the FTC's theory was "just not borne out in actual market data." 141 Dr. Nevo explained that according to the FTC's theory, Qualcomm's royalty rates should be higher during the time period of its alleged market power in CDMA modem chips and premium LTE model chips. ${ }^{142}$ However, Dr. Nevo's statistical analysis of Qualcomm's royalty agreements from 19902017 showed there was no economic or meaningful difference between royalty rates during the time period of Qualcomm's alleged market power and the royalty rates outside of such period. ${ }^{143} \mathrm{He}$ also presented evidence that ex ante royalty rates did not significantly increase upon implementation of either the CDMA or LTE standards, which were periods when Qualcomm's market power was allegedly at its apex. ${ }^{144}$ Dr. Nevo also examined industry performance during the time period of Qualcomm's alleged anticompetitive conduct and found that the industry had been thriving and was characterized by declining prices and skyrocketing quantities. ${ }^{145}$

This case is particularly notable in that the FTC's complaint and pretrial brief is built largely on Dr. Shapiro's bargaining model. ${ }^{146}$ Yet, the district court judge, Judge Lucy Koh-while accepting the FTC's positions and conclusion of harm-never makes a single reference to Dr.

\footnotetext{
139. Id

140. FTC v. Qualcomm Inc., 411 F. Supp. 3d 658, 761 (N.D. Cal. 2019).

141. Transcript of Proceedings on January 25, 2019 at 1864, FTC v. Qualcomm Inc., 411 F. Supp. 3d 658 (N.D. Cal. 2019) (No. 17-CV-00220).

142. Id. at $1866-68$.

143. Id.

144. Id. at $1871-75$.

145. Id. at 1902-03.

146. Complaint at 73, FTC v. Qualcomm Inc., 411 F. Supp. 3d 658 (N.D. Cal. 2019) (No. 17-CV00220) ("the parties' expectations about the probable outcome of litigation determine the negotiated terms. In this sense, bargaining over royalties and other licensing terms occurs 'in the shadow of the law."'); Pretrial Brief at 13, Qualcomm Inc., 411 F. Supp. 3d 658 (No. 17-CV-00220) ("Qualcomm's no license-no chips policy fundamentally alters the bargaining dynamic. Qualcomm's monopoly power in premium CDMA and premium LTE modem chips means that OEMs would find losing the ability to purchase modem chips from Qualcomm extremely costly. In this setting, basic bargaining theory predicts that Qualcomm's no license-no chips policy, by allowing Qualcomm to bring leverage from its market power in modem chips to bear on license negotiations, will lead to royalties that exceed the reasonable royalties that Qualcomm would otherwise obtain."); id. at 12 ("Professor Shapiro will provide an economic analysis of Qualcomm's leverage. Professor Shapiro will explain that, absent its no license-no chips policy, Qualcomm would negotiate licenses as other cellular-SEP holder do-in the shadow of the law.").
} 
Shapiro's bargaining model or report in her 233-page opinion. ${ }^{147}$ Rather, Judge Koh largely bases her decision on a legal conclusion that Qualcomm has an antitrust duty to deal with rival chipset makers and license its SEPs to them. ${ }^{148}$ This omission of any reference to Dr. Shapiro, his bargaining model, or his report suggests, but certainly does not prove, that the district court found the bargaining model problematic on some dimension. It is particularly striking because the model's predictions are consistent with her ultimate ruling that Qualcomm's conduct harmed competitors. ${ }^{149}$ It seems highly probable that, while sympathetic to the model and its predictions, the judge felt the model was sufficiently unreliable, that it would increase the probability of reversal, and that its inclusion in the decision did not outweigh its costs.

\section{FTC v. Advocate Health Care}

In Advocate Health Care, defendants were two hospital networks in the northeastern Illinois region, Advocate Health Care Network and NorthShore University Health System, that proposed to merge in 2014. ${ }^{150}$ The FTC's economic expert, Dr. Steven Tenn, developed a structural model to prove anticompetitive effects of the proposed merger based on diversion ratios, margins, and relative prices. ${ }^{151}$ Notably, Dr. Tenn relied on a structural, price-setting model-rather than an explicit bargaining model - because, according to the court, "it is easier to understand than a bilateral bargaining-based model and certain economic literature, including some that specifically addressed the hospital industry, shows that the price-setting model and the bilateral bargaining model will 'generate identical predicted post-merger price increases." 152 The defense criticized Tenn's model as inconsistent with commercial realities of how prices are set and presented in a standard WTP-bargaining model. ${ }^{153}$ Nonetheless, the court found that Dr. Tenn's model demonstrated that the merger would likely result in anticompetitive harm and, additionally, that defendants' criticisms of the model were superficial

\footnotetext{
147. See FTC v. Qualcomm Inc., 411 F. Supp. 3d 658 (N.D. Cal. 2019).

148. Id. at 760. ("[B]ecause Qualcomm previously licensed its rivals, but voluntarily stopped licensing rivals even though doing so was profitable ...."); see also Edwards, Ginsburg \& Wright, supra note 131 , at 2 .

149. See id.

150. See Fed. Trade Comm'n v. Advocate Health Care, No. 15C11473, 2017 WL 1022015, at*1 (N.D. Ill. Mar. 16, 2017).

151. Id. at $* 8$.

152. $I d$. at $* 10$.

153. Id. at $* 11$.
} 
and unconvincing. ${ }^{154}$ In fact, Dr. Tenn criticized the defense's implementation of the WTP-bargaining model and noted that it suffered from endogeneity bias and produced implausible results. ${ }^{155}$ Thus, this case is notable because it represents the FTC moving away from its standard WTP-bargaining model to a more structural and deterministic model based on ease of exposition and reduced computational burden and assumptions. Whether this move is specific to this case or perhaps an indicator of a more general trend clearly remains to be seen.

\section{E. Laumann v. National Hockey League}

National Hockey League involves a class action antitrust lawsuit challenging the territorial exclusivity of hockey and baseball broadcasting implemented by the respective leagues. ${ }^{156}$ Specifically, plaintiff claimed that the National Hockey League (NHL) and Major League Baseball (MLB) conspired with regional sports networks (RSNs) to maintain a system of "territorial exclusivity" that limited viewing options and artificially raised prices. ${ }^{157}$ Plaintiff's expert was Dr. Roger Noll, who designed an economic model "to simulate how consumers and RSNs would behave if territorial restrictions were lifted." 158 In essence, Dr. Noll attempted to measure the counterfactual world where RSNs can offer their programming a la carte to consumers outside of their specific region. ${ }^{159}$ For example, Atlanta Braves broadcasts could be viewed by "out-ofmarket" subscribers in the Washington, D.C. area, rather than having these consumers rely solely on packages like MLB.tv to watch the Braves. Dr. Noll based his model on Crawford and Yurukoglu ${ }^{160}$ and examined the impact on consumer welfare from unbundling television channels from cable packages. ${ }^{161}$ As part of Dr. Noll's estimates of the counterfactual world, he decided to not model the bargaining process between RSNs and MVPDs for the price of their a la carte services; ${ }^{162}$ rather, he used

\footnotetext{
154. Id. at $* 10$.

155. Id. at*11. In one exercise, "Dr. Tenn simulated a merger of all 48 hospitals that Dr. McCarthy [the parties' economic expert] identifies as competing with at least one of defendants' hospitals. ... Dr. Tenn calculated that, using the defense experts' mode of analysis, the post-merger price change would range from $33 \%$ decrease, which is patently absurd, to a modest $6 \%$ increase, which is too small to be plausible for such a large area." Id.

156. Laumann v. Nat'l Hockey League, 117 F. Supp. 3d 299 (S.D.N.Y. 2015).

157. Id. at 302 .

158. Id. at 304 .

159. Id.

160. Gregory S. Crawford \& Ali Yurukoglu, The Welfare Effects of Bundling in Multichannel Television Markets, 102 AM. ECON. REV. 643 (2012).

161. Laumann, 117 F. Supp. 3d at 304.

162. This is in contrast to the analysis performed in Crawford \& Yurukoglu, supra note 160.
} 
assumptions regarding the state of competition to determine the equilibrium price. ${ }^{163}$

In assessing a Daubert challenge, Judge Shira Scheindlin was rather critical of Dr. Noll's demand-side analysis to estimate demand for a la carte programming. ${ }^{164}$ However, Judge Scheindlin accepted Dr. Noll's decision to not model bargaining in his supply-side analysis of how RSNs and MVPDs would interact. ${ }^{165}$ Dr. Noll's rationale for not modeling bargaining was that internet delivery of RSN content is a substitute for delivery over an MVPD. ${ }^{166}$ Consequently, MVPDs would have no bargaining leverage to mark up prices above the competitive equilibrium. ${ }^{167}$ In essence, all the bargaining leverage is with the RSNs; thus, there is no need to model the bargaining process. ${ }^{168}$ Judge Scheindlin emphasized, however:

By assuming that it is unnecessary to model bargaining between RSNs and MVPDs in the BFW ["but-for world"], Dr. Noll is not suggesting that no bargaining between the RSNs and MVPDs would occur. He is suggesting that to capture the results of bargaining between RSNs and MVPDs in the BFW, it is unnecessary to model the process of bargaining. ${ }^{169}$

It is unclear how Judge Scheindlin would have ruled if Dr. Noll had used a bargaining framework; although, it appears, at least implicitly, there is judicial support to avoid the necessity of model bargaining if there are alternative, more structural approaches to estimating the result of the bargain. This is similar to Dr. Tenn's rationale for avoiding the WTPbargaining model in Advocate Health Care. ${ }^{170}$

\section{F. Behrend v. Comcast}

In Behrend, plaintiffs were cable television subscribers who sued Comcast for alleged violations of Sections 1 and 2 of the Sherman Act. ${ }^{171}$

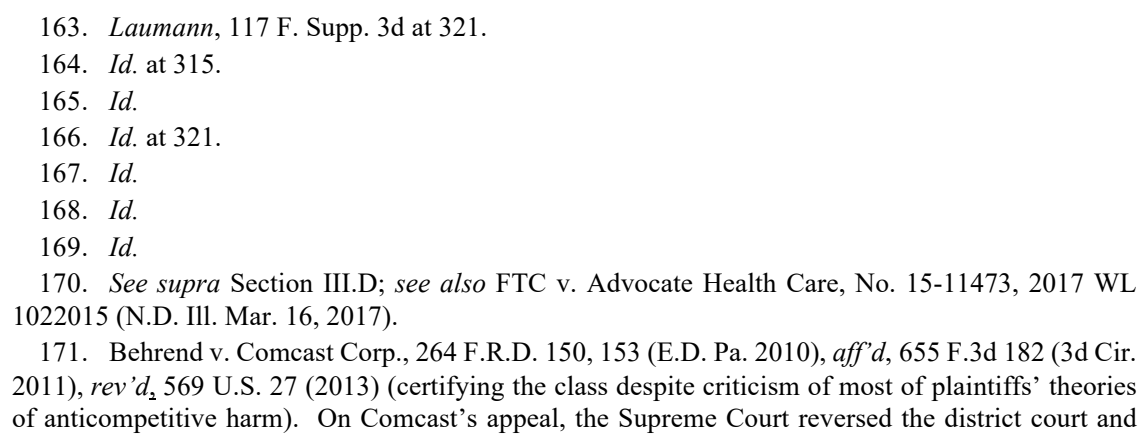

171. Behrend v. Comcast Corp., 264 F.R.D. 150, 153 (E.D. Pa. 2010), aff'd, 655 F.3d 182 (3d Cir. 2011), rev'd 569 U.S. 27 (2013) (certifying the class despite criticism of most of plaintiffs' theories of anticompetitive harm). On Comcast's appeal, the Supreme Court reversed the district court and 
Plaintiffs offered a bargaining model to outline the harm incurred by cable users when a cable operator increases its footprint within a particular region through a practice called "clustering." 172 Plaintiffs' expert, Dr. Michael Williams, asserted that when a cable provider increases its regional strength through clustering, it increases its bargaining power when negotiating terms with content providers, such as cable networks. ${ }^{173}$ According to Dr. Williams, this increase in bargaining power manifests itself in two ways. ${ }^{174}$ First, he relied on Ken Binmore et al. and theorized that with increased clustering, cable networks become relatively less patient during negotiations while cable operators become relatively more patient and, thus, become more likely to break off negotiations. ${ }^{175}$ The effect is that Comcast would extract more of the bargaining surplus because of its greater patience. ${ }^{176}$ Second, Dr. Williams introduced a novel assumption that there is information asymmetry about whether the particular cable network has "favorable or unfavorable" advertising rates. ${ }^{177}$ This asymmetry allowed Dr. Williams to arrive at a result where Comcast's greater bargaining power actually resulted in higher prices for their end consumers (when we would normally believe lower input costs will lower prices assuming some degree of cost pass-through). ${ }^{178}$

Judge John Padova agreed with Comcast's economic experts, Dr. David Teece and Dr. Tasneem Chipty, who were highly critical of Dr. Williams' bargaining model—with Dr. Teece calling it "perverse and unrealistic."179 In particular, Judge Padova found Dr. Williams' foundational assumption - that there is information asymmetry on advertising rates - to be "wholly unsupported." 180 Further, Judge Padova stated that the model was "unsupported by any evidence that cable

appellate court decisions and rejected class certification. Comcast Corp. v. Behrend, 569 U.S. 27 (2013).

172. Berhend, 264 F.R.D. at 159. This is where, through a series of acquisitions or asset swaps with other cable providers, a cable provider concentrates its operations in a particular region-in this case the Philadelphia "Designated Market Area" (DMA) that included counties in Pennsylvania, Delaware, and New Jersey. Id. at 191.

173. Id. at $157-58$.

174. Id. at $178-80$.

175. Id. (citing Binmore et al., supra note 48).

176. Id.

177. Id.

178. Id. at 179-80. To arrive at this result, the expert developed a model where, in order to create the proper incentive for the cable network to honestly signal whether or not advertising rates are high or low, the cable provider will commit to reducing the number of its own end consumers receiving the channel via higher cable rates. Id. In sum, when the cable provider has greater bargaining power, it results in lower input costs but also an incentive to raise prices in order to incentivize the cable network to be honest about its adverting rates.

179. Id. at 180 .

180. Id. at 181 . 
operators actually engage in this negotiating conduct" and also "unsupported by any empirical evidence." 181 Interestingly, Dr. Williams' attempt to tailor the bargaining model to the specifics of this casenamely, the assumption regarding information asymmetry on advertising rates - was severely criticized by both the defense and the court. ${ }^{182}$ Most likely, it was not the tailoring per se that was problematic but the particular choice in tailoring. Further, it appears that the court was critical of the bargaining model even without the particular tailoring.

While the district court judge ultimately approved certification of a class of Comcast subscribers based on a specific claim of antitrust harmnamely, that clustering deterred entry - it rejected other claims including the alleged anticompetitive harm based on the shift in bargaining power between Comcast and the cable networks. ${ }^{183}$ While the Court of Appeals affirmed, ${ }^{184}$ the Supreme Court reversed based on a finding that the class was improperly certified because the damages estimated by the plaintiff were overly broad and did not narrowly measure the harm from the specific aspect of the antitrust claim that was accepted-i.e., that clustering deterred entry. ${ }^{185}$ The Supreme Court's decision did not weigh in on the merits of Dr. Williams' bargaining model.

\section{G. United States v. AT\&T}

In $A T \& T$, the DOJ alleged that AT\&T's purchase of Time Warner would result in anticompetitive harm due to the combination of upstream and downstream assets in video programming and distribution. ${ }^{186}$ Specifically, inter alia, by combining AT\&T's downstream DirecTV division with Time Warner's upstream Turner networks, this would result in higher input costs for rivals to DirecTV-like Dish Network-in the form of higher affiliate fees, i.e., the per subscriber per month fee. ${ }^{187}$ The government's expert, Dr. Carl Shapiro, used a bargaining model to estimate the increase in fees likely to result from the vertical integration. ${ }^{188}$ Dr. Shapiro posited that the combined company would enjoy increased bargaining leverage since the opportunity cost of striking a deal with

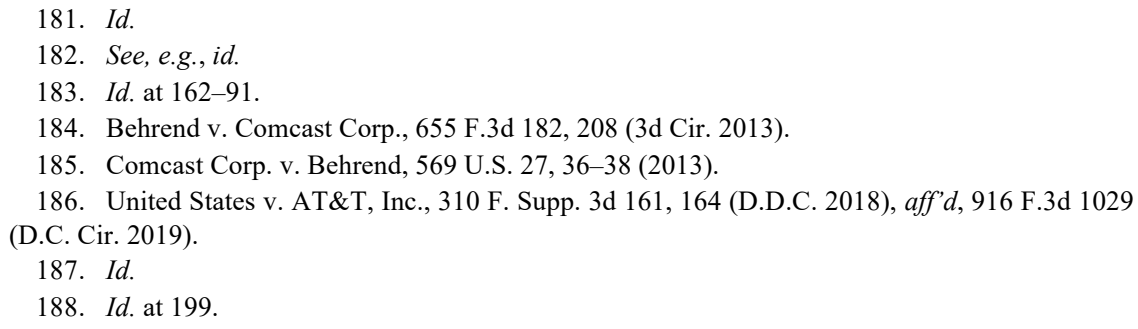


DirecTV's downstream rivals would be higher post-merger. ${ }^{189}$ The logic is that a stronger downstream rival with Turner content diminishes the profitability of the DirecTV division. Put somewhat differently, a longterm blackout, which would result if Turner content is not carried by rivals, is less costly to the combined entity since a blackout would actually help the DirecTV division - assuming some positive diversion. ${ }^{190}$ The purpose of Dr. Shapiro's bargaining model was to quantify the benefits that would flow to AT\&T from a long-term blackout of Turner content provided by AT\&T's competitors. ${ }^{191}$ Importantly, the point was not to actually predict that a long-term blackout would occur, but to illustrate how it would be more beneficial to AT\&T's DirecTV post-merger. ${ }^{192}$ Consequently, this increase in benefits would increase Time Warner's ex ante bargaining leverage. ${ }^{193}$

In his decision, Judge Richard Leon was clearly convinced that the procompetitive aspects of the merger were quite strong. ${ }^{194}$ Yet his ruling in favor of the merger was also highly influenced by his view that the bargaining model was inadequate; specifically, he concluded that "the Government has failed to clear the first hurdle of showing that the proposed merger is likely to increase Turner's bargaining leverage."195 Most of the opinion was devoted to providing support for this conclusion. First, Judge Leon emphasized that actual bargaining is innately unpredictable. ${ }^{196}$ Second, he was unconvinced of the strength of the bargaining leverage in the first place and concluded that "Turner's content is not literally 'must have' in the sense that distributors cannot effectively compete without it. The evidence showed that distributors have successfully operated, and continue to operate, without the Turner networks or similar programming." ${ }^{\prime 197}$ This finding obviously discounts the actual harm from a blackout.

Third, Judge Leon found that "to prove its increased-leverage theory,

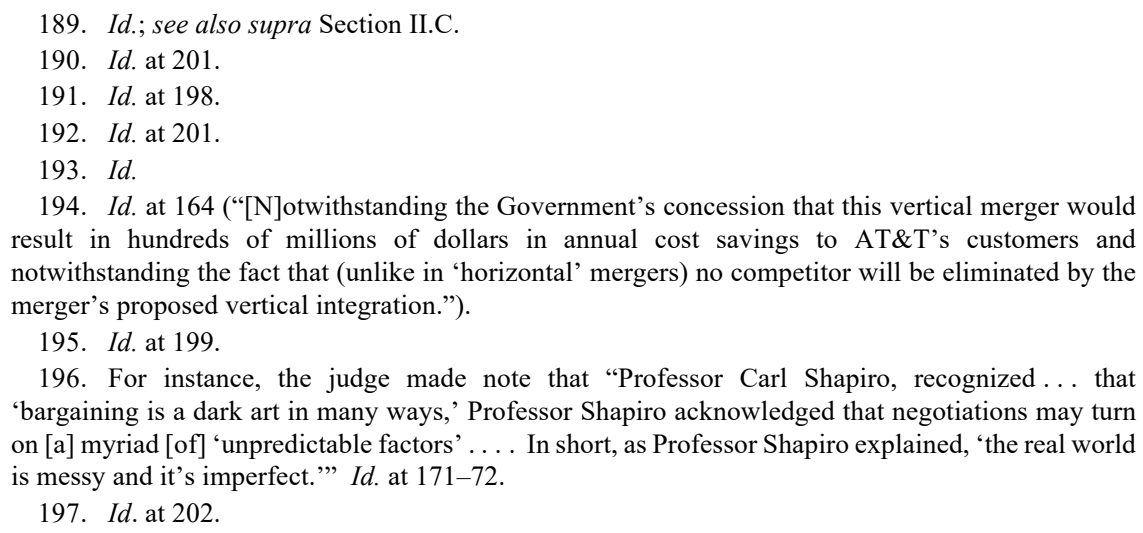

196. For instance, the judge made note that "Professor Carl Shapiro, recognized... that 'bargaining is a dark art in many ways,' Professor Shapiro acknowledged that negotiations may turn on [a] myriad [of] 'unpredictable factors' .... In short, as Professor Shapiro explained, 'the real world is messy and it's imperfect." Id. at 171-72.

197. Id. at 202 . 
the Government relie[d] upon random statements from defendants' 'ordinary course' business documents, including employees' emails and internal slide decks." 198 Thus, he believed that these documents lacked the weight needed to support the leveraging model. ${ }^{199}$ This rationale echoes skepticism of bargaining models from the courts in Virnet $X{ }^{200}$ Limelight, ${ }^{201}$ and Behrend. ${ }^{202}$ Instead, Judge Leon credited the empirical evidence offered by the defenses' economic expert, Dr. Dennis Carlton, which showed a lack of price increases from past instances of vertical integration. ${ }^{203}$ Further, he opined that "the integration of programming and distribution does not affect affiliate negotiations." ${ }^{\text {"204 }}$ Consequently, combining the DirecTV and Time Warner divisions would have no impact on bargaining leverage. ${ }^{205}$ Finally, according to Judge Leon, even if he accepted the bargaining model, "the evidence is also insufficient to support the input values upon which [Shapiro] relied to generate his predictions of harms.",206

198. Id. at 208 .

199. Id. at 210 ("[T] his is not a case containing direct, probative evidence of anticompetitive intent on the part of high-level executives within the merging company."); id. at 212 ("Much of the thirdparty competitor testimony [the judge] heard consisted of speculative concerns regarding how the witnesses thought Turner might act in negotiations after the merger."); id. at 214 ("[T]he record is barren of any contentions by the third-party competitors that they would actually give in to any price increases demanded by Turner as a result of its purported increase in post-merger leverage.").

200. VirnetX, Inc. v. Cisco Sys., Inc., 767 F.3d 1308 (Fed. Cir. 2014).

201. Limelight Networks v. XO Commc'ns, No. 3:15-CV-720, 2018 WL 678245 (E.D. Va. Feb. 2, 2018).

202. Behrend v. Comcast Corp., 264 F.R.D. 150 (E.D. Pa. 2010).

203. United States v. AT\&T, 310 F. Supp. 3d 161, 215-17 (D.C.C. 2018), aff'd, 916 F.3d 1029 (D.C. Cir. 2019).

204. Id. at 218 .

205. Commentators have been particularly critical of this finding that negotiators do not consider other divisions or units of a company when bargaining. See, e.g., Salop supra note 52, at 462 . While the court does offer some evidentiary support for this judgement (e.g., testimony of negotiating executives), it can run counter to standard economic models of profit maximization which assume maximization occurs over the entire suite of products and divisions at a firm. Id. On appeal, the D.C. Circuit also highlights this as a potentially problematic aspect of the decision - particularly the failure to cite Copperweld Corp. v. Independent Tube Co., 467 U.S. 752, 771 (1984), which effectively upheld the principle that a business with multiple divisions will maximize corporate-wide profits. United States v. AT\&T, Inc., 916 F.3d 1029, 1043 (D.C. Cir. 2019). That being said, Amicus for 37 Economists provides economic arguments in support of the court's ruling. Brief Amici Curiae of 37 Economists, Antitrust Scholars, and Former Government Antitrust Officials Supporting Appellees and Supporting Affirmance at 17, United States v. AT\&T, Inc., 916 F.3d 1029 (No. 18-5214) (“[M]ultidivision firms face a multitude of decisions about when to exercise centralized control and when to allow divisions to operate in a decentralized manner.").

206. $A T \& T, 310 \mathrm{~F}$. Supp. $3 \mathrm{~d}$ at 221 . The court spends a considerable portion of the opinion detailing the weaknesses of the inputs used in the bargaining model. See id. passim. Ultimately, however, the judge's logic does not rest on the quality of the inputs but rather on the credibility of whether or not bargaining leverage materially increases post-merger. See infra Part IV. This would be consistent with the court in Limelight, which stated that the issue was not whether or not the "right" 
On appeal, the D.C. Circuit Court affirmed the district court's ruling and, in particular, stated that Judge Leon did not misunderstand or misapply the Nash bargaining theory. ${ }^{207}$ Rather, the court reiterated much of the same arguments that Judge Leon relied upon, including the fact that plaintiff's bargaining model "failed to take into account Turner Broadcast System's post-litigation irrevocable offers of no-blackout arbitration agreements." 208 Further, the court cited Virtnet $X$ : "As one circuit has put it, ' $[\mathrm{t}]$ he Nash theorem arrives at a result that follows from a certain set of premises,' while the theory 'asserts nothing about what situations in the real world fit those premises." 209 In sum, the court stated "the record shows that the district court accepted the Nash bargaining theory as an economic principle generally but rejected its specific prediction in light of the evidence that the district court credited." 210

\section{What Role Should Bargaining MOdELS Play IN ANTITRUST CASES?}

Given the overview of recent cases involving bargaining models, it is clear that court adoption, interpretation, and evidentiary requirements have been uneven at best. We can broadly divide the previously discussed set of cases into three categories: (1) cases determining counterfactual patent royalties; (2) cases involving horizontal mergers of hospitals; and (3) cases involving vertical integration in media markets. In this Part, we comment on the courts' treatment of bargaining models within the context of each category to determine how bargaining models were assessed. We particularly focus on the bargaining model used in $A T \& T$ and find that the court's logic in rejecting the predictions of increased bargaining leverage are well founded under certain assumptions.

\section{A. Patent Royalty Counterfactuals}

In both Virnet $X$ and Limelight, the courts were asked to determine the counterfactual royalty amount for certain patents. ${ }^{211}$ This involved assessing whether Nash's bargaining model led to reliable predictions for

\footnotetext{
weighted average cost of capital (WACC) was used to calibrate relative bargaining patience but whether the WACC measure was relevant at all to understand the bargaining outcome. Limelight, 2018 WL 678245 , at *3.

207. United States v. AT\&T, Inc., 916 F.3d 1029, 1039-40 (D.C. Cir. 2019).

208. Id. at 1031 .

209. Id. at 1039 (alteration in original) (quoting VirnetX, Inc. v. Cisco Sys., Inc., 767 F.3d 1308, 1332 (Fed. Cir. 2014)).

210. Id.

211. Virnetx, 767 F.3d at 1325-26; Limelight, 2018 WL 678245, at *2.
} 
counterfactual negotiations. These cases illustrate that courts can struggle with some of the abstractions necessary to model the bargaining outcome - such as the central Nash bargaining assumption of equal bargaining power. In Limelight, attempts to refine the Nash bargaining assumption and tailor the bargaining power estimate to particulars of the case actually resulted in greater judicial skepticism. ${ }^{212}$ Given the somewhat singular focus of the courts in both Virnet $X$ and Limelight in determining the adequacy of the bargaining model, it appears that the burden is perhaps higher in cases where the primary exercise is to determine the counterfactual royalty amount that would have emerged in some hypothetical bargaining situation. ${ }^{213}$ The two courts were reticent to engage in hypothetical exercises where the underlying assumptions were not properly developed and justified. ${ }^{214}$ Yet, that is the essence of economic modeling, which necessarily involves abstractions and simplifications. But ultimately, the power of models lie in their ability to predict outcomes. Thus, any theoretical model based on abstractions and simplifications will suffer the from the critique of the Limelight court that "it relies on an expert's willingness to offer an opinion on what would have occurred in a negotiation that did not occur and never would have occurred, since the parties show no willingness to negotiate." ${ }^{215}$ Yet, behind the court's rejection of the particular bargaining model is an important premise: the parties were allegedly unwilling to negotiate."216 This premise may or may not be accurate, given the facts of the case, but its accuracy could be further developed with evidence. Thus, the Limelight court was perhaps a bit heavy-handed in its criticism of economic abstractions, but it was also potentially justified in questioning the premise that the parties would be negotiating at all.

Qualcomm clearly represents a very different case than Virnet $X$ and Limelight because, while it involved patent royalties, it was in the context of SEPs, FRAND, and alleged monopoly power in certain types of

212. Limelight, $2018 \mathrm{WL} 678245$, at *3 (stating that the expert's use of relative patience, from Rubinstein, to measure bargaining power was no better than "fancy guesswork"); see also Rubinstein, supra note 44 and accompanying text.

213. This is in contrast to horizontal and vertical mergers where courts are weighing a plethora of other factors including market definition, multiple theories of harm, entry, and efficiencies. Specifically, to the extent bargaining models are used to predict competitive harm, it is weighed along with other evidence that inform this question including documents, testimony, and other empirical evidence. In other words, bargaining models are generally not the only piece of evidence used to prove anticompetitive harm in merger cases.

214. See, e.g., supra Sections III.A-B.

215. Limelight Networks, Inc. v. XO Commc'ns, LLC, No. 3:15-CV-720, 2018 WL 678245, at *2 (E.D. Va. Feb. 2, 2018).

216. Id. 
chipsets. ${ }^{217}$ Consequently, Qualcomm lacks a singular focus in determining the counterfactual patent royalty. As noted previously, Judge Koh ultimately agreed with the conclusion of anticompetitive conduct; however, she did not rely on the FTC expert's bargaining model or expert report. ${ }^{218}$ At the very least, this reasonably suggests that there is judicial discomfort with basing a finding of anticompetitive harm on a bargaining framework - even if used merely to support or corroborate evidence. As the court in Virnet $X$ indicated, although courts appear to routinely accept Nash bargaining models and assumptions to determine counterfactual patent royalties, the acceptance is uneven; furthermore, some courts have outright rejected the Nash bargaining models. ${ }^{219}$ Thus, the question is not necessarily related to the quality of the inputs used in the model, but whether the entire model is appropriate at all. ${ }^{220}$

\section{B. Hospital Merger Cases}

Within antitrust jurisprudence, the most common use and acceptance of bargaining models occurs in horizontal hospital merger cases. In some sense, plaintiffs' successful use of bargaining models in hospital mergers is the gold standard by which all other models are assessed. However, in Advocate Health Care, the FTC did not use the WTP-bargaining modelwhich the defendants actually utilized ${ }^{221}$ — but rather, used a structural model that did not rely on bargaining assumptions. ${ }^{222}$ In fact, commenting on the analysis used in the case, the FTC's economic expert, Dr. Tenn stated:

There are, of course, multiple ways of undertaking a merger simulation. For example, one alternative approach that the FTC could have employed was a Price-Willingness to Pay (WTP) regression, which seeks to estimate the relationship between price and a measure of

217. See FTC v. Qualcomm, Inc., No. 17-CV-00220, 2018 WL 5848999 (N.D. Cal. Nov. 6, 2018).

218. See supra Section III.C and accompanying text.

219. See Limelight Networks, 2018 WL 5848999, at *2.

220. While a discussion of empirical support of the predictions of Nash's bargaining models is beyond the scope of this article, there certainly is some evidence that Nash's bargaining model is a poor predictor of real-world outcomes. See, e.g., HANS J.M. PETERS, AXIOMATIC BARGAINING GAME THEORY 13 (1992) ("Empirical evidence for the Nash bargaining solution certainly is not overwhelming .... Further, many experiments have been conducted-see Roth and Malouf (1979) for an overview - but also these are not unambiguously conclusive in favor of the Nash solution. Even, earlier experiments by Crott (1971) point in the direction of the next popular solution, the RaiffaKalai-Smorodinsky solution.").

221. FTC v. Advocate Health Care, No. 15-C-11473, 2017 WL 1022015 (N.D. Ill. Mar. 16, 2017).

222. See id. The approach that Dr. Tenn utilized was based on Gaynor et al., which is based on a differentiated Bertrand model. See Martin S. Gaynor et al., A Structural Approach to Market Definition with an Application to the Hospital Industry, 61 J. INDUS. ECON. 243 (2013). 
bargaining leverage by predicting the change in price that would occur from the parties' increased bargaining leverage postmerger. But employing this regression risked raising complicated econometric issues that would have been difficult to resolve in this case and was therefore not the analysis the FTC's economic expert considered most appropriate. ${ }^{223}$

Of course, econometric problems are not problems with the bargaining model per se, but it suggests that the data requirements to implement hospital bargaining models are not trivial and can expose the expert to a great deal of criticism.

Importantly, recent research by a former FTC economist, Christopher Garmon, indicates that use of the WTP-bargaining model as a screening device to identify presumptively anticompetitive hospital mergersalthough superior to simply looking at market concentration- has a fairly high error rate in predicting post-merger price changes when combined with merger simulation. ${ }^{224}$ Garmon's study is the first comprehensive examination of the various predictive tools used for hospital mergers in a large sample of mergers. ${ }^{225}$ It is important to note that Garmon's paper only focuses on the WTP tool as a screening device with data that is typically available early in an investigation rather than as a tool during a full phase investigation when potentially more data is used. Using a sample of 28 hospital mergers, Garmon found that the WTP screen correctly identified 7 of the 9 mergers that resulted in significant price increases, ${ }^{226}$ although, that means the WTP screen had a false negative (type II error) in 2 of the 9 mergers. ${ }^{227}$ Further, of the 19 non-problematic mergers, the WTP screen correctly identified 12 of the $19 ;{ }^{228}$ thus, it triggered a false positive (type I error) for 7 of the 19 cases. ${ }^{229}$ In total, the WTP screen correctly identified the direction of the ultimate price effect for 19 of the 28 mergers (67.9 percent) ${ }^{230}$ and incorrectly identified the direction for 9 of the 28 mergers (32.1 percent). ${ }^{231}$ To account for the fact that some of the false positives could be due to eventual cost savings,

223. Tenn \& Vandergrift, supra note 65 , at $6 \mathrm{n} .24$.

224. Garmon, supra note 10, at 1097. Garmon states that "it is important to emphasize that the screens are being evaluated to determine how well they identify mergers that warrant further investigation, not how well they identify anticompetitive mergers in isolation from other evidence." Id. at 1087.

225. Id. at 1097 .

226. Id. at 1089 \& tbl.3.

227. Id. tbl.3.

228. Id.

229. Id.

230. Id.

231. Id. 
Garmon dropped mergers that resulted in variable cost savings. ${ }^{232}$ The results still show a significant percentage of false positives and negatives. ${ }^{233}$ Ultimately, Garmon found that "WTP . . leave[s] a great deal of unexplained variation in the price changes, even excluding mergers with cost savings. ... This highlights that methods that approximate the lost competition from a merger like WTP ... may miss some merger effects that impact price." 234 Specifically, WTP is "useful for flagging mergers for further investigation, but not for identifying anticompetitive mergers on [its] own apart from other evidence.... WTP-based merger simulation performs poorly at predicting post-merger price changes, but this may be due to the limited data available to calibrate the simulation in an initial investigation." 235

Again, because the focus of Garmon's research is on WTP (and other measures) as a screening tool, caution must be exercised in extrapolating too much from the results. Nonetheless, retrospective studies like Garmon's are tremendously useful in giving some empirical validity to bargaining models such as WTP, which are used routinely in agencies and courts. The takeaway is that these models can result in a significant percentage of false positives and negatives. Consequently, courts and practitioners should certainly seek to determine whether the WTPbargaining model is appropriate in the particular merger at hand.

\section{Bargaining Models in Vertical Mergers in Media Markets}

Although bargaining models, and their structural variants, are well accepted by courts in horizontal hospital mergers, this is certainly not the case for media markets. In Laumann, the court appeared to offer judicial support for avoiding the necessity of bargaining models if alternative approaches are available. ${ }^{236}$ In Behrend, the district court was highly critical of the bargaining model used by the plaintiff to measure the harm incurred by cable users when a cable operator increases its footprint within a particular region, i.e., "clustering." 237 Further, the court found the bargaining model had no empirical support and was "perverse" given

\footnotetext{
232. Id. at 1089 .
}

233. According to Garmon, there are seventeen mergers without variable cost savings. Id. tbl.4. Of those seventeen, eight have a significant post-merger price increase. Id. The WTP measure fails to identify two of the eight. Id. Further, the WTP measure improperly flags two of the nine nonproblematic mergers. Id.

234. Id. at 1093.

235. Id. at 1097.

236. See Laumann v. Nat'l Hockey League, 117 F. Supp. 3d 299 (S.D.N.Y. 2015).

237. See Behrend v. Comcast Corp., 264 F.R.D. 150 (E.D. Pa. 2010). 
certain assumptions made by the expert. ${ }^{238}$

While bargaining models were used extensively by the FCC in the Comcast-NBCU matter, the case was settled and, thus, we have no direct insight into how a court would have received the bargaining model developed in that case. We do have an indirect insight, however, because AT\&T-Time Warner involved a very similar bargaining model. ${ }^{239}$

Ultimately, in $A T \& T$, Judge Leon's rationale for rejecting the bargaining model came down to finding a "low likelihood of a long-term Turner blackout." ${ }^{240}$ Judge Leon emphasized that mere possibilities of blackout are insufficient, rather, the threat of a blackout must be credible. $^{241}$ The issue of credibility was also directly addressed by the D.C. Circuit. ${ }^{242}$ In this Part, we walk through the judge's reasoning for rejecting the predictions of the bargaining model-focusing on the issue of blackout credibility.

We start by focusing on the district court's belief that the evidence strongly showed that the goal of Turner networks was to increase distribution as widely as possible. ${ }^{243}$ Judge Leon cited Turner Chairman and CEO John Martin who stated, "our goal is to have our networks in front of as many eyeballs as possible." 244 Judge Leon summarized the testimony in this area by stating, "[f] or that reason, Turner executives aim to achieve wide distribution of their networks," 245 because "wide distribution maximizes programmers' two income streams - affiliate fees and advertising revenue." 246

With his focus on wide distribution, Judge Leon properly emphasized that Turner network channels are two-sided platforms, although he did not use this specific terminology. ${ }^{247}$ Two-sided platforms, including ad-

238. Id. at 180 .

239. See supra notes $156-82$ and accompanying text

240. United States v. AT\&T, Inc., 310 F. Supp. 3d 161, 207 (D.D.C. 2018), aff'd, 916 F.3d 1029 (D.C. Cir. 2019).

241. Id. at 223 .

242. United States v. AT\&T, Inc., 916 F.3d 1029, 1040 (D.C. Cir. 2019) (“[W]hether the threat of long-term blackouts would be credible, as posited by the government's increased leverage theory.").

243. $A T \& T, 310$ F. Supp. 3d at 169.

244. Id. at 168 .

245. Id. at 169 (internal quotation marks and citation omitted).

246. Id. at 171.

247. Id. at 195. Two-sided platforms, such as radio and television stations, bring two "sides" or groups together, such as viewers and advertisers, on a common platform, e.g., a specific television channel. Platforms are characterized by the existence of cross-group effects, or indirect network effects, which are triggered when the presence and size of one group, e.g., viewers, attracts members of the other group, e.g., advertisers. The cross-group effects do not necessarily need to be symmetrical or even positive in both directions - but it needs to be positive in at least one direction. See, e.g., JeanCharles Rochet \& Jean Tirole, Platform Competition in Two-Sided Markets, 1 J. EuR. ECON. Ass'N 
supported channels, attempt to unlock indirect network effects, or crossgroup effects, through wide distribution of their products. ${ }^{248}$ As viewership increases, this attracts advertisers and increases adverting rates. Importantly, part of the efficiency justification for the deal is that the advertising will become more targeted and efficient. ${ }^{249}$ If so, then the expected return to advertising will increase post-merger if there is an increase in advertising rates. ${ }^{250}$ Consequently, the post-merger incentive to increase distribution is even higher.

This recognition of the importance of advertising revenue is further illustrated by Judge Leon, who reasoned that "[n]umerous witnesses explained, and Professor Shapiro acknowledged, that a long-term blackout of Turner content, even post-merger, would cause Turner to lose more in affiliate fee and advertising revenues than the merged entity would gain." 251 Further, "[u]nlike the car seller, who might be "willing to walk away' and accept his alternative offer to sell the car for a gain ... the evidence at trial indicated that Turner would not be willing to accept the 'catastrophic' affiliate fee and advertising losses associated with a longterm blackout." $" 252$

Questioning the credibility of the blackout threat is further bolstered by the parties' commitment to offer baseball-style arbitration for licensing disputes. ${ }^{253}$ As part of the terms of the arbitration, Turner must continue to supply content during dispute periods, thus, "the commitment guarantees that no blackout of Turner content can occur once arbitration is invoked." 254 This is a highly key consideration because this structurally eliminates the primary engine behind consumer harm from bargaining models. Without the increased opportunity cost from striking a deal, there is no change in incentives; consequently, there is also no change in bargaining leverage since the possibility of a blackout has been eliminated.

990 (2003); David S. Evans, The Antitrust Economics of Multi-Sided Platform Markets, 20 YALE J. REG. 325 (2003).

248. See, e.g., David S. Evans, What Times-Picayune Tells Us About the Antitrust Analysis of Attention Platforms, CPI ANTITRUST CHRON., Apr. 2019, at 1, 3 ("Platforms set prices recognizing that there is a feedback loop connecting the two sides. That results in their balancing prices between the two sides in a way that ensures that they have enough participants on each side to create value for those on the other side. Commonly, platforms set prices below cost on one side, because they can charge the other side more to get access to those on the subsidized side.").

249. AT\&T, $310 \mathrm{~F}$. Supp 3d at 254. "AT\&T will also, with their customers' permission, use consumer data to develop targeted ads, thereby increasing the value of Time Warner's ad inventory." Id. at 183 .

250. See, e.g., id. at 182 ("AT\&T's digital, data-driven advertising prices are $60 \%$ higher than Nielsen-based ads because the former have "finer demographics that are offered for targeting."').

251. Id. at 223 .

252. Id. at 223 n. 35 .

253. Id. at 217 .

254. Id. at 184 . 
Thus, it is perfectly consistent with the bargaining model to incorporate this structural constraint as well.

In sum, what appears to lie behind Judge Leon's dismissal of the DOJ's theory of harm is the fundamental rejection of a change in the Turner networks' post-merger bargaining leverage. ${ }^{255}$ As previously mentioned, television channels like the Turner networks seek wide distribution to maximize their return on advertising revenue, which is based in large part on the number of viewers. ${ }^{256}$ Further, since Judge Leon fully embraced the procompetitive aspects of the merger-including the synergies involved with more efficient advertising - those returns would only be higher post-merger. ${ }^{257}$ This consideration actually drives down the post-merger bargaining leverage. Thus, coupled with the arbitration agreement, the criticisms against Judge Leon-based on erroneous assertions or misunderstandings of bargaining models - are inaccurate. That being said, both the district court and the D.C. Circuit discuss the "credibility" of a blackout threat, which is a bit of an imprecision. ${ }^{258}$ The issue is more about changes in bargaining leverage and whether that change is materially different post-merger (and reliability calculated).

\section{POLICY IMPLICATIONS AND CONCLUSION}

If we assume that the best outside option during negotiations between upstream channels and downstream programming distributors is a blackout, then mergers such as Comcast-NBCU and AT\&T-Time Warner will always exhibit upward pricing pressure-regardless of the level of market power upstream or downstream. ${ }^{259}$ This is effectively a "built-in" result from use of bargaining models in the context of vertical mergers. It is important to note that this does not necessarily mean a predicted postmerger price increase since efficiencies have not been accounted for; although, it certainly changes the evidentiary debate if all vertical mergers involving bargaining have an upward pricing pressure.

The mechanical use of bargaining models in this manner is effectively the same as applying a vGUPPI to all vertical mergers. While there has been some recent advocacy to incorporate vGUPPIs into a desired revision of the vertical merger guidelines, ${ }^{260}$ the FTC's draft 2020 Vertical Merger

\footnotetext{
255. Id. at 207.

256. Id. at 171 .

257. Id. at 195 .

258. United States v. AT\&T, Inc., 916 F.3d 1029, 1040 (D.C. Cir. 2019).

259. See supra Section II.C.

260. See Salop, supra note 52, at 459.
} 
Guidelines did not include vGUPPIs. ${ }^{261}$ Further, the antitrust agencies do not appear to routinely incorporate vGUPPIs into assessments of vertical mergers. ${ }^{262}$ The question is why? As discussed below, a number of recent papers examine the feasibility and predictive qualities of vGUPPIs (and, by extension, bargaining models that generalize the vGUPPI result).

Margaret Slade reviewed the usefulness of vGUPPIs in antitrust matters and found that "[a] vertical GUPPI, while sharing the disadvantages of the horizontal GUPPI, [loses] some of its advantages."263 The primary disadvantages are (i) the informational requirements are higher because information must be obtained on non-merging rivals, which requires who exactly are the rivals (which invokes relevant product market considerations); (ii) three vGUPPI calculations are necessary rather than one; and (iii) one of the vGUPPI calculations requires a vector of cost passthroughs. ${ }^{264}$ Given these shortcomings, Slade concludes that "vertical GUPPIs should not be used as screening tools, that is, as tools for deciding which mergers warrant further investigation." 265 While acknowledging that, for contested mergers, vGUPPIs can be useful-they must be considered simultaneously with the elimination of EDM according to the work of Gopal Das Varma and Martino De Stefano. ${ }^{266}$

Gopal Das Varma and Martino De Stefano developed a bargaining model for vertical mergers that integrates the incentive to raise rivals' costs (RRC) through a change in bargaining leverage (or, as a special case, the vGUPPI) with the elimination of EDM. ${ }^{267}$ They found that "standard" bargaining models that do not explicitly and jointly model these two concepts results in errant price predictions. ${ }^{268}$ For instance, a standard bargaining model "assumes that the merging downstream firm's retail price, and the rival's output, remain at their pre-merger levels. Thus, the calculation ignores the demand shift effect that stems from EDM."269

261. See U.S. Dep'T of Justice \& Fed. Trade Comm'N, Draft Vertical Merger Guidelines (2020), https://www.ftc.gov/system/files/documents/public_statements/1561715/p810034vertical mergerguidelinesdraft.pdf [https://perma.cc/8WA8-3L74].

262. See, e.g., Int'l Competition Network, ICN Vertical Mergers Survey Report, at 16 (2018), https:/www.internationalcompetitionnetwork.org/wp-content/uploads/2018/10/MWG_Surveyreport VerticalMergers2018.pdf [https://perma.cc/Q6Q5-M3HU] ("vGUPPI, on the other hand, is infrequently used: 29 out of 40 [National Competition Authorities] indicated have never used this technique.").

263. Margaret Slade, Vertical Mergers: Ex Post Evidence and Ex Ante Evaluation Methods 11 (Vancouver Sch. of Econ., Working Paper, 2020).

264. Id. at $11-12$

265. Id. at 12 .

266. See generally Das Varma \& De Stefano, supra note 10.

267. Id. at $2-3$.

268. Id. at 19 .

269. Id. at 11 
Further, they found that different assumptions regarding relative bargaining power can actually result in different post-merger price change predictions. ${ }^{270}$

Using a different methodology, Gleb Domnenko and David Sibley also examined the ability of vGUPPIs to accurately predict post-merger price changes. ${ }^{271}$ Specifically, they compared Monte Carlo merger simulations with the predictions from vGUPPIs. They concluded that, "[g]iven these simulation results, we calculate vGUPPI indices in two alternative ways and find that they are not useful predictors of the directions upstream prices take after a vertical merger. vGUPPIs for the upstream price to be paid by the remaining downstream rival always predict increases, whereas in 58 percent of the simulations, the upstream price falls after the merger." 272 While vGUPPIs are not identical to recent bargaining models used in vertical mergers, as detailed in Section II.C, they are close cousins - particularly in their built-in prediction of upward pricing pressure from all vertical mergers. ${ }^{273}$ Consequently, the criticisms of vGUPPI also generally apply to vertical bargaining models.

Our review of the use of bargaining models in prior antitrust cases is not intended to dismiss the usefulness of bargaining models in antitrust. Rather, a degree of caution is required when using a bargaining model in a manner that does not fit its actual scope. Bargaining models allow us to gain important insights and inferences from a process that inherently is difficult to predict. There are a variety of factors that influence the direction of the prediction. Game theory is a powerful tool that has tremendous applications both within economics and outside of economics. Yet, according to Drew Fudenberg and David Levine, there are circumstances when "game theory does a poor job empirically: for example, when equilibria are not robust, the environment is complex, or when circumstances are unfamiliar, standard game theory is less likely to perform well in the sense of making too wide a range of predictions." 274 When properly assessed, this divergence between theoretical predictions and empirical results suggests that the theory is only as good as the underlying assumptions; and often, what is required are refinements and developments in the theory to conform to the empirical realities. ${ }^{275}$

270. Id. at $12-13$.

271. See generally Domnenko \& Sibley, supra note 10.

272. Id. at 4.

273. Id. at 16

274. Drew Fudenberg \& David K. Levine, Whither Game Theory? Towards a Theory of Learning in Games, 30 J. ECON. PERSP. 151, 153 (2016).

275. See DAVID K. LeVInE \& Jie Zhang, HANDBook of Experimental ECONOMiC 
Further, Luke Froeb et al. explain that "predictions are sensitive to a particular bargaining model's assumptions. This raises the question of reliability of the predictions in merger cases: When predictions depend on assumptions, it is important to determine how well the particular model 'fits' the case or industry to which it is applied." 276

In sum, bargaining models certainly have a useful place in a competition agency's toolkit to predict the effects of mergers or various unilateral conduct; however, their use should be limited by fact-specific evidence. Economists relying on bargaining models to advance theories of harm must ensure that the model is built on robust assumptions about how the industry actually operates. If a model makes predictions that are plainly contradicted by real world data, one must ask whether something is wrong with the model. We find that Judge Leon's opinion in $A T \& T^{277}$ is a good example of how to balance complex modeling against other evidence. Judges should carefully examine theoretical models alongside other economic and testimonial evidence to determine whether the model accounts for and holds up against market realities. ${ }^{278}$

Further, even if a model is applicable, the estimates of the effects are only as accurate as the inputs used. While this is an obvious point, it is worth emphasizing that EDM and efficiencies are central to most vertical mergers. ${ }^{279}$ Consequently, the estimated magnitudes of both the harm and efficiencies are particularly important to accurately assess in order to make reliable predictions. A key aspect of the DOJ's bargaining model in AT\&T involved measuring the rate of subscriber loss from content distributors (such as Dish Network) in the face of higher content costs from Turner channels such as TBS and TNT. ${ }^{280}$ The court rightly wrestled over the accuracy and reliability of the measure presented by the DOJ—as this was

Methodology, The Relationship Between Economic Theory and Experiment (Guillaume R. Fréchette \& Andrew Schotter, 2015); see also Laumann v. Nat'l Hockey League, 117 F. Supp. 3d 299, 303 (S.D.N.Y. 2015) ("For this reason, 'even where an expert's methodology is reliable, if the analysis is not based upon relevant and reliable data, the expert's opinion will be inadmissible." (quoting Johnson Elec. N. Am. Inc. v. Mabuchi Motor Am. Corp., 103 F. Supp. 2d 268, 283 (S.D.N.Y. 2000))).

276. Luke M. Froeb et al., Economics at the Antitrust Division: 2017-2018, 53 REV. INDUS. ORG. 637, 645-46 (2018).

277. See United States v. AT\&T Inc., 310 F. Supp. 3d 161 (D.D.C. 2018), aff'd, 916 F.3d 1029 (D.C. Cir. 2019).

278. This is also the point made by the Amicus of 37 economists. Brief Amici Curiae of 37 Economists, Antitrust Scholars, and Former Government Antitrust Officials Supporting Appellees and Supporting Affirmance at 17, United States v. AT\&T, Inc., 916 F.3d 1029 (D.C. Cir. 2019) (No. 185214) ("The district court found that, although Nash bargaining can be a useful approach to evaluating mergers in some cases, the empirical evidence in this case did not support the government's claims, even when viewed through the lens of Nash bargaining.").

279. See Francine Lafontaine \& Margaret Slade, Vertical Integration and Firm Boundaries: The Evidence, 45 J. ECON. LITERATURE 629 (2007).

280. See $A T \& T, 310$ F. Supp. 3d. at 225-34. 
a key input to measure the change in the post-merger bargaining strength of AT\&T. ${ }^{281}$

Ultimately, we find that judges are not rejecting the Nash bargaining model per se, but are rejecting its application to a particular matter and its predictive power given the specific set of facts and information requirements. This is an important distinction. 